\title{
Implementation and Evaluation of Teach-back as a Pedagogical Method for Delivering Fall Prevention Education to Older Adults in an Inpatient Hospital Setting
}

Elizabeth Bosley

Follow this and additional works at: https://researchrepository.wvu.edu/etd

\section{Recommended Citation}

Bosley, Elizabeth, "Implementation and Evaluation of Teach-back as a Pedagogical Method for Delivering Fall Prevention Education to Older Adults in an Inpatient Hospital Setting" (2016). Graduate Theses,

Dissertations, and Problem Reports. 5237.

https://researchrepository.wvu.edu/etd/5237

This Dissertation is protected by copyright and/or related rights. It has been brought to you by the The Research Repository @ WVU with permission from the rights-holder(s). You are free to use this Dissertation in any way that is permitted by the copyright and related rights legislation that applies to your use. For other uses you must obtain permission from the rights-holder(s) directly, unless additional rights are indicated by a Creative Commons license in the record and/ or on the work itself. This Dissertation has been accepted for inclusion in WVU Graduate Theses, Dissertations, and Problem Reports collection by an authorized administrator of The Research Repository @ WVU.

For more information, please contact researchrepository@mail.wvu.edu. 
Implementation and Evaluation of Teach-back as a Pedagogical Method for Delivering Fall Prevention Education to Older Adults in an Inpatient Hospital Setting

Elizabeth Bosley MSN, RN

\section{Doctoral Research Project Submitted to the School of Nursing at West Virginia University}

in partial fulfillment of the requirements for the Doctor of Nursing Practice Degree

Jennifer Mallow, Ph.D., RN

Laurie Theeke, Ph.D., RN, FNP-BC, GCNS-BC, FNAP

E. Lee Taylor M.D., J.D.

Morgantown, West Virginia

2016

Keywords: Teach-back, falls, inpatient, older adults, nursing, patient education, hospital, falls prevention

Copyright 2016 Elizabeth Bosley 


\section{ABSTRACT \\ Implementation and Evaluation of Teach-back as a Pedagogical Method for Delivering Fall Prevention Education to Older Adults in an Inpatient Hospital Setting}

Elizabeth Bosley

Background: In the United States, the most common cause of both nonfatal injuries and accidental deaths for people older than 65 is falls. In the hospital setting, 700,000 to 1,000,000 falls occur annually resulting in increased cost and reduced reimbursement. There exists a critical need to explore potential interventions for effectiveness in reducing both the incidence and severity of falls. Teach-back is a patient education methodology that is a highly recommended safety practice and may be an effective intervention to reduce patient falls in the hospital setting.

Objectives: 1) To increase the use and documentation of a validated patient education methodology by registered nurses to decrease falls in patients 65 years of age and older in a specific hospital unit. 2) To decrease the rate of falls and falls with injury in patients 65 years of age and older in a specific hospital unit through implementation of the Teach-back patient education methodology.

Method: A quasi-experimental design was used employing a combination of parametric and non-parametric tests to analyze the data for both objectives. Objective One: Two hundred and forty older adult patients comprised the sample. The independent variable was Teach-back education for nurses. The dependent variables were using a caring tone of voice and attitude, displaying comfortable body language, using plain language, providing falls prevention patient education using Teach-back, using open-ended questions, avoiding using yes or no questions, taking responsibility for making sure instructions were clear, explaining instructions again if patients could not Teach-back and documenting the use of Teach-back. Nurses were observed teaching 120 patients about falls prevention prior to Teach-back education and then observed teaching 120 patients about falls prevention following Teach-back education. Objective Two: The independent variable was falls prevention patient education using Teach-back. The dependent variables were falls and falls rate with injury per 1000 patient days. These rates were compared for February, March, and April of 2015 (pre-education) and February, March and April of 2016 (post-education).

Results: Objective One: Analysis of the data indicated no association existed between the independent variable (Teach-back education for the nursing staff) and the dependent variables of using a caring tone of voice and attitude, displaying comfortable body language and using plain language. Statistically significant associations did exist between the independent variable and the remaining six dependent variables. Objective Two: Analysis of the data indicated that there was no significant difference in falls or falls with injury per 1000 patient days between the two timeframes.

Conclusion: Nurses consistently used and documented Teach-back for falls prevention education once provided with the procedure and rationale thereby utilizing an evidence-based methodology to improve communication with the patient. Although there was no significant relationship between Teach-back and falls and falls with injury per 1000 patient days, the simplicity and potential efficacy of Teach-back warrants further study. 


\section{Dedication}

This work is dedicated to my wonderful husband Tom who chose to embark on this journey with me 38 months ago. I could not have possibly made it through without his patience, advice, and superbes et magnifiques editing skills! His support, whether praise or tough constructive criticism, always came from a place of love and I'm a better person for it.

I also dedicate this work to my mother Dorothy Sowards, who has always been my greatest cheerleader. Her unflagging interest in my progress exemplifies what a mother will endure to help their child achieve their dreams.

Finally, I thank my family, especially my siblings, Bill, Marty, and Louise for always pitching in to make sure life went on so I could devote my time and energy toward my education, and to our wonderful daughters, Meghan and Jennifer, I thank you for listening and supporting me. 


\section{Acknowledgements}

I owe a great deal of gratitude to my Chair, Dr. Jennifer Mallow, who has the patience of Job. I will always appreciate her unfailing willingness to provide guidance throughout this process. I send many thanks to Dr. Laurie Theeke for not only her participation on my committee and providing helpful feedback but also for truly broadening my horizons in our informatics class. I also thank Dr. Lee Taylor for agreeing to participate on my committee. In spite of his many personal and professional responsibilities, Dr. Taylor has taken the time to act as a sounding board and has been a valuable source of support and perspective.

I want to especially acknowledge the following faculty of the school of nursing with many thanks for sharing their knowledge and challenging me to open my mind to what is possible.
Dr. Emily Barnes
Dr. Susan Coyle
Dr. Stacy Culp
Dr. Gina Maiocco
Dr. Georgia Narsavage
Dr. Mary Jane Smith
Dr. Sheila Stephens 


\section{Table of Contents}

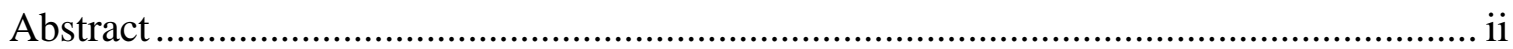

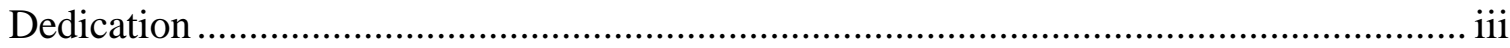

Acknowledgments.................................................................................................. iv

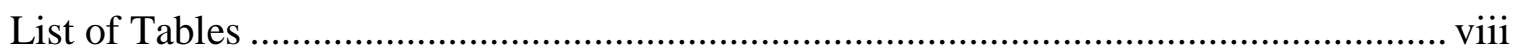

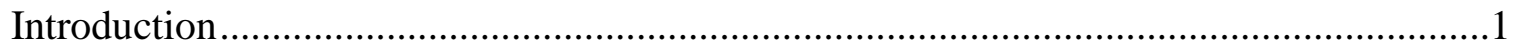

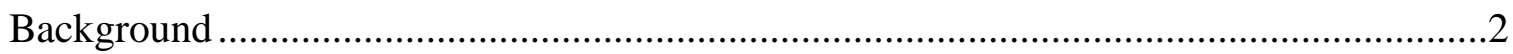

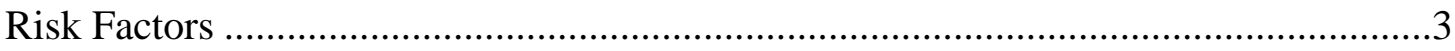

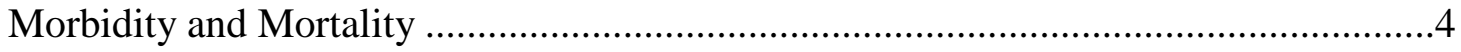

Potential Barriers to Implementation .........................................................................

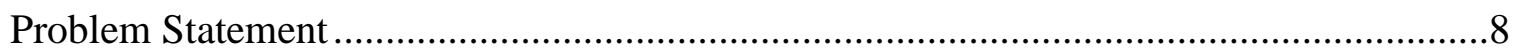

Population and Demographics .................................................................................

Clinical Site: Falls Incidence, Cost, and Standard of Practice..........................................9

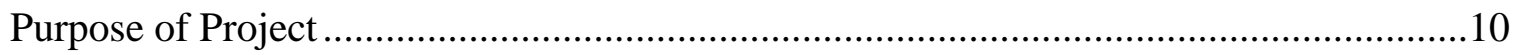

Significance of Project .......................................................................................................12

Literature Review and Synthesis ..............................................................................13

Search Strategies .............................................................................................13

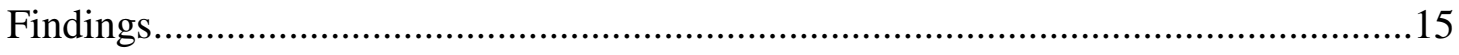

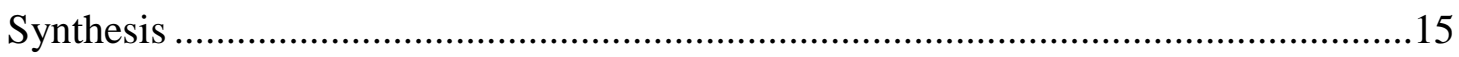

Theoretical Framework: Orem’s Self-Care Deficit Nursing Theory ..................................16

Theory of Self-Care ..............................................................................................

Theory of Self-Care Deficit ......................................................................................17

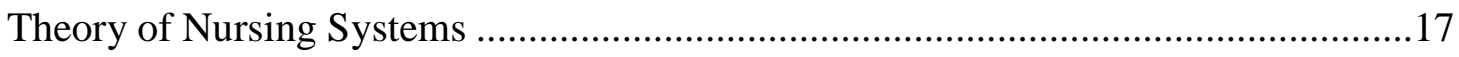

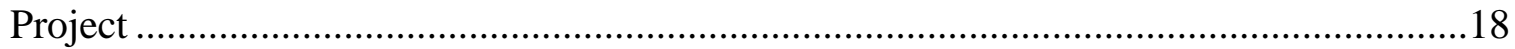

Project Design ......................................................................................................18

Project Procedure ………………………………………………………………......19

Strengths, Weaknesses, Opportunities and Threats ........................................................19 


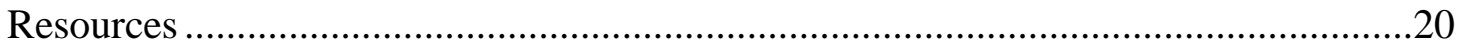

Congruence with Organization's Strategic Plan to the Clinical Project........................20

Evidence of Key Site Support.............................................................................21

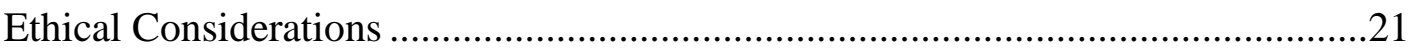

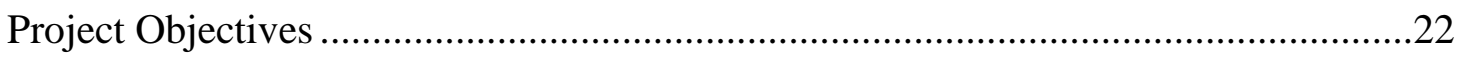

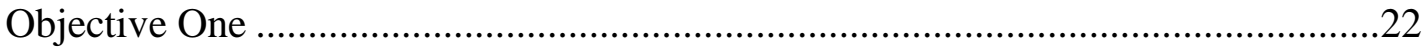

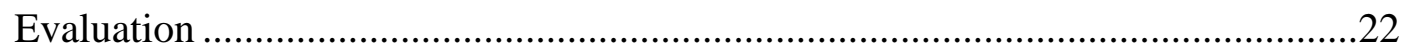

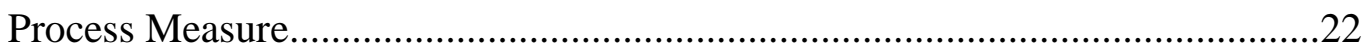

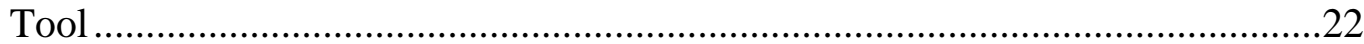

Data Collection and Analysis Procedures...........................................................22

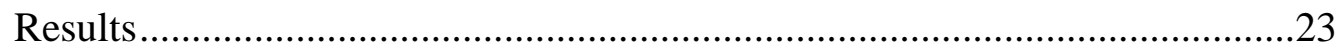

Demographics ……………………………………………......................23

Table 1: Summary of Scores from the “Always Use Teach-back”!

Observation Tool ......................................................................................24

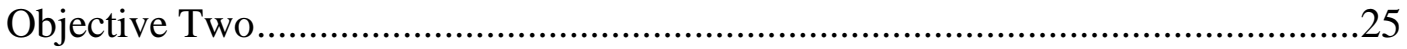

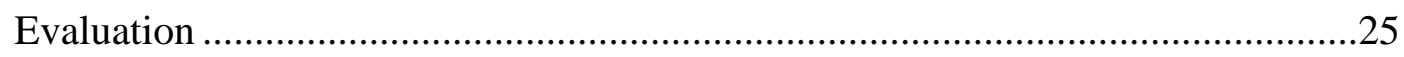

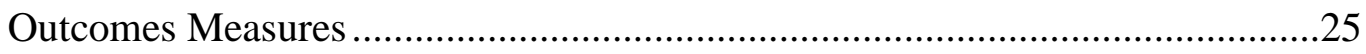

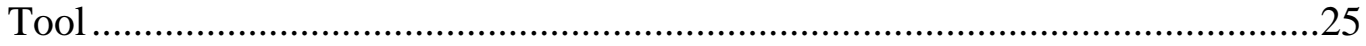

Data Collection and Analysis Procedures..........................................................25

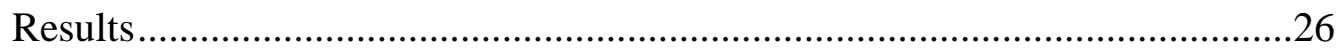

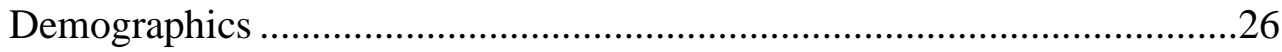

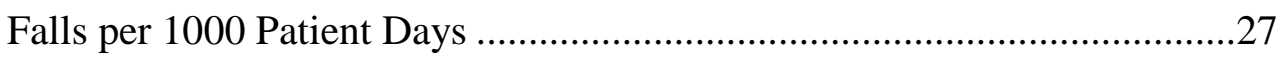

Falls with injury per 1000 Patient Days.........................................................28

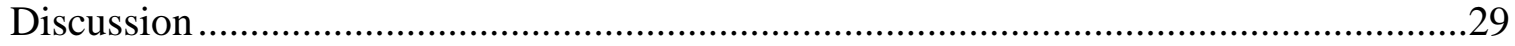

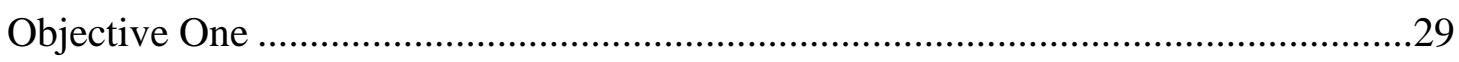

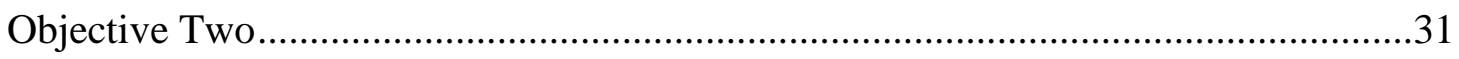

Support of Theoretical Model....................................................................................32

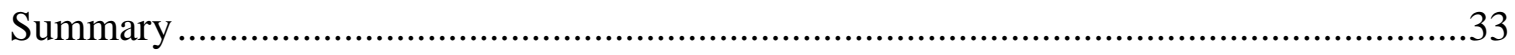




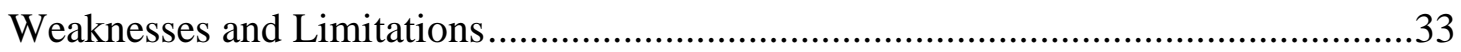

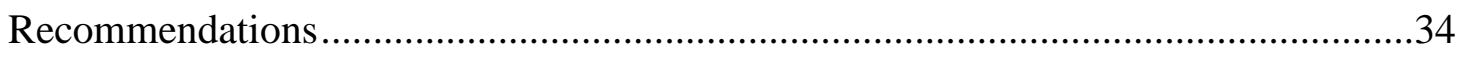

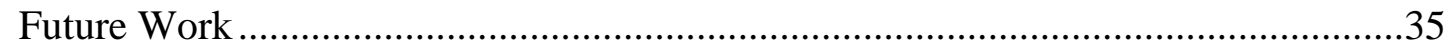

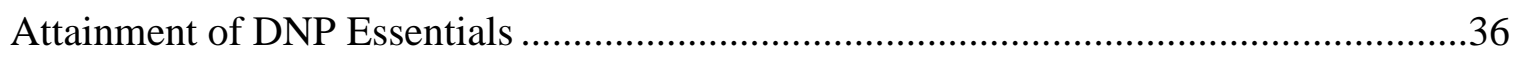

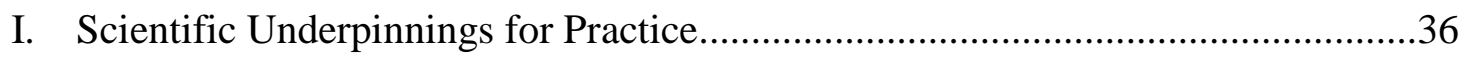

II. Organizational and Systems Leadership for Quality Improvement and Systems

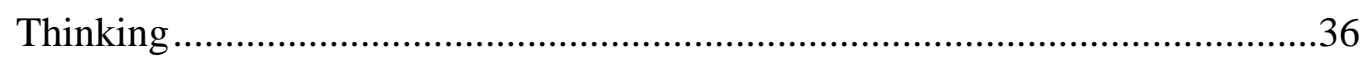

III. Clinical Scholarship and Analytical Methods for Evidence-Based Practice .........37

IV. Information Systems/Technology and Patient Care Technology for the Improvement and Transformation of Health Care...............................................37

V. Health Care Policy for Advocacy in Health Care .....................................................37

VI. Interprofessional Collaboration for Improving Patient and Population Health....38

VII. Clinical Prevention and Population Health for Improving the Nation’s Health ...38

VIII. Advanced Nursing Practice...................................................................................39

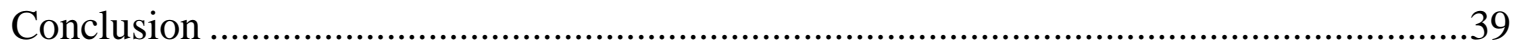

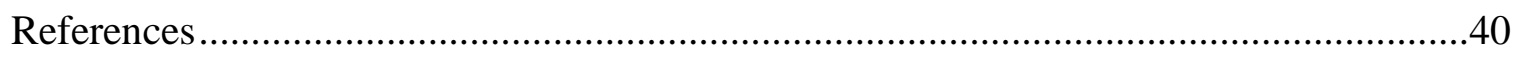

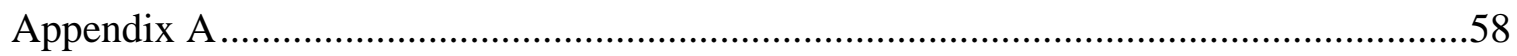

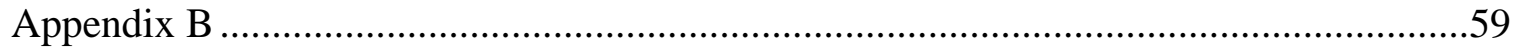

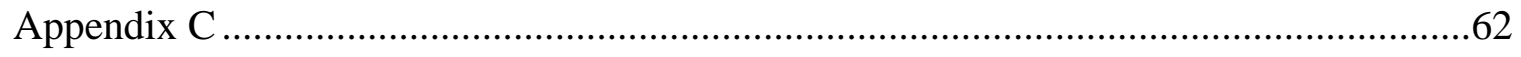

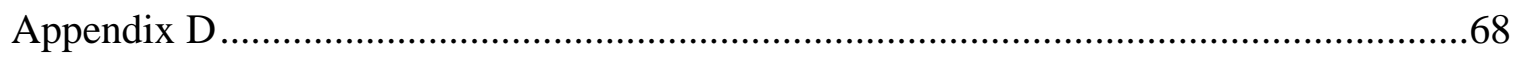

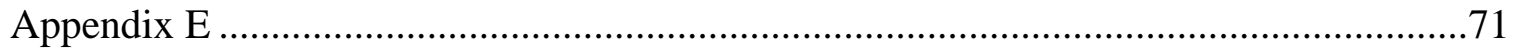

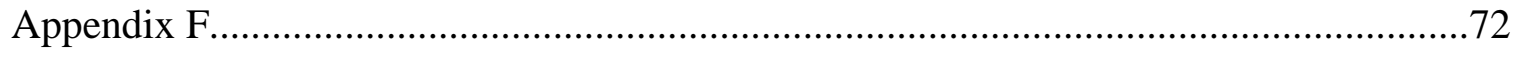

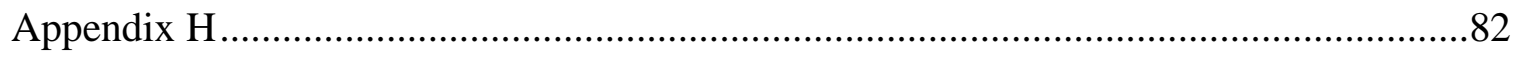

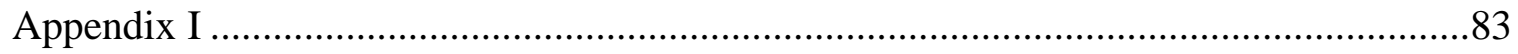

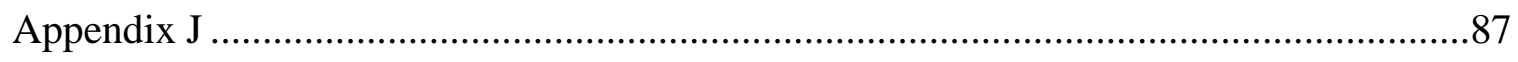

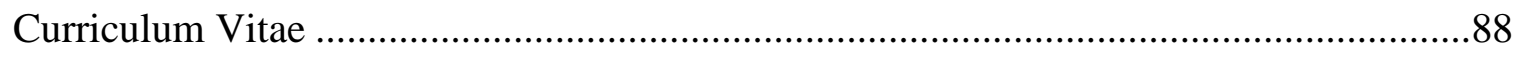




\section{List of Tables}

TABLE Page

1. Summary of Scores from the “Always Use Teach-back!” Observation Tool......24

2. Literature Review Findings

Comprehension and Retention of Information.................................72

3. Literature Review Findings

Comprehension and Retention of Information on Specific Outcomes.............77 


\section{Introduction}

A fall in the hospital setting is defined as an unplanned descent which results in a person coming to rest inadvertently on the ground or floor with or without injury (National Database of Nursing Quality Indicators [NDNQI], 2014; World Health Organization [WHO], 2012). In the United States, the most common cause of both nonfatal injuries and accidental deaths for people older than 65 years of age is falls (Centers for Disease Control and Prevention [CDC], 2015). In a hospital setting, patients 65 years and older are at greater risk for falls because both chronological age and physical functional losses associated with aging contribute to increased risk of falling (Currie, 2008). It is estimated that between 700,000 and 1,000,000 falls occur in hospitals annually, adding an average of 6.3 days to the hospital stay at an average cost of \$14,056.00 per event (Bouschon, et al., 2012; Currie, 2008; Haines et al., 2013; Hitcho et al., 2004). The physical injuries sustained from falls can range in severity from fractures to intracerebral bleeding, and lead to permanent disability, loss of independence and even death. Psychological injury attendant to a fear of falling can result in social isolation, depression and feelings of helplessness (Hsu, 2004; World Health Organization [WHO] 2007). Patient deaths from fall related injuries in the hospital setting, while infrequent, must still be of concern. The Joint Commission (2014) reported that there are 11,000 deaths nationally of hospitalized patients occurring each year from falls.

Since falls have such a tremendous impact on health outcomes and the healthcare system, numerous initiatives have been undertaken as potentially effective solutions to preventing falls. The purpose of this project is to implement and evaluate Teach-back as a pedagogical method for delivering fall prevention education to older adults in an inpatient hospital setting. 


\section{Background}

In the hospital setting, falls are the second most reported adverse event, following only medication errors (Agency for Healthcare Research and Quality [AHRQ], 2014). Nationally, in 2013, it was noted that \$34 billion dollars (adjusted for inflation) was spent on the direct medical costs of falls (CDC, 2015). For the hospitalized older adult, a fall can have devastating consequences. Oliver, Healey and Haines (2010) have reported that up to $20 \%$ of inpatients fall at least once during their hospitalization with injuries occurring in up to $51 \%$ of falls. Of those, as many as $44 \%$ of patients experience serious injuries, some even resulting in death. The effects and costs of a fall will rarely end with the initial hospitalization. Some older adult patients suffer more permanent disability and require expensive short or long term care post-discharge (Currie, 2008). Once discharged, they may become increasingly dependent upon others and will report a reduced quality of life. (Hsu, 2004; World Health Organization [WHO] 2007).

For hospitals, inpatient falls can also result in devastating outcomes. In 2008, the Centers for Medicare and Medicaid (CMS) classified falls as a hospital acquired condition (HAC) describing this condition as one that is high cost and/or high volume which can be preventable if evidence based guidelines are used (Radey \& LaBresh, 2012). CMS has ceased reimbursing hospitals for the costs associated with injuries related to inpatient falls and private insurers are following their example (CMS, 2009; Fuhrmans, 2008). In addition, attendant expense of litigation, the threat of litigation, and negative community perceptions of the safety of the hospital can contribute to further costs and reduced reimbursement associated with falls (Amplion Clinical Communications, n.d.). 
Complicating the issue of falls is the rapid growth of the demographic cohort known as "Baby Boomers", who are now reaching the age of 65. In 2010, there were 40.4 million people in the United States 65 years of age and older. This population is projected to increase to 72.1 million by 2030 (U.S. Department of Health and Human Services, 2011) Within this burgeoning cohort it has been found that as many as 40 percent of people over the age of 65 will fall each year. Further, those 80 years of age and older have been reported to fall at a rate of 50 percent, with 60 percent of those having a history of falls in the previous year (Soriano, DeCherrie \& Thomas, 2007; U.S. Preventive Services Task Force, 2012); The United States Department of Health and Human Services has recognized that the cost of falls is unsustainable in light of the swiftly increasing numbers of people who are now reaching the age of 65 . In response, a goal for injury prevention for older adults has been included in the department's ten year plan with priorities to improve health, function and quality of life. This plan for all Americans is known as Healthy People 2020 (Healthy People 2020, 2015). Given these findings, there exists a critical $\underline{\text { need }}$ to explore potential interventions for effectiveness in reducing both the incidence and severity of these events. (Kiel, 2014; Rubenstein, 2006).

\section{Risk Factors}

The risk factors that contribute to falls in adults aged 65 years and older result from a progressive functional decline that begins early in life and continues in a linear pattern (Bowen \& Atwood, 2004). It is most often a combination of physiologic changes of aging and the pathology of disease that contributes to the mortality and morbidity of patients (Martin \& Sheaff, 2007). For example, an older adult patient's reduced capacity to accommodate normal kinetic forces can, with concomitant osteoporotic disease, result in fall-associated fractures (Aschkenasy \& Rothenhaus, 2006). 
Similarly, no single factor necessarily places an older adult at risk but a combination of factors can increase vulnerability to falls (Rubenstein, 2006; World Health Organization, 2007). Inouye, Studenski, Tinetti and Kuchel (2007) studied falls in the older adult population and concluded that at least two of the following risk factors were present: "older age, history of falls, functional impairment, cognitive impairment or dementia or low activity level and balance abnormality” (p.6). In addition, an increase in the more narrow-based stance of older adults, when coupled with balance and gait abnormalities, foot ulcers, deformities, and reduced plantar cutaneous sensation are also contributory to fall risk. Specifically, true functional lower extremity weakness and associated balance effects were found to be sentinel independent predictors of a non-faller becoming a faller (Inouye et al., 2007; Melzer, Benjuya \& Kaplanski, 2004; Muir, Berg, Chesworth \& Speechley, 2010; Rubenstein, 2006).

Risk factors have been classified as intrinsic and extrinsic. Intrinsic risk factors such as a prior history of falls, gender, ethnicity, medication effects, medical conditions (including reduced vision and hearing), sedentary behaviors, fear of falling and nutritional deficiencies exist and have an even greater impact on adults 80 years of age or older (Michael et al., 2010). Extrinsic factors would be those that are external to the patient and include environmental issues such as slippery floors, uneven surfaces, shoes, clothing and usage of inappropriate assistive devices (Todd and Skelton, 2004).

\section{Morbidity and Mortality}

Although injuries do not always occur in a fall, falls are the leading cause of fatal and non-fatal injuries among older adults. Deaths from falls occur less frequently than injury although mortality rates have been reported as high as 11 percent (CDC, 2015; Aschkenasy et al., 
2006; Kiel, 2014). It should also be appreciated that the apparent severity in individual fallrelated scenarios does not always serve as a predictor of mortality in the older adult population. Konstantinos et al. (2010) found that 4.5 percent of older adult patients 70 years and older died after falls occurring at "ground level". More troubling is the finding that approximately one-half of older adults admitted to a hospital after falling will not be alive one year later (Rubenstein, 2006).

Morbidity following an injury sustained from a fall can be very significant. Kiel (2014) estimated that as many as 75 percent of older adults are unable to resume their pre-injury activity status. Kiel also notes that specifically contributory to this is the fall-related phenomenon described as the "long lie". The older adult patient that falls and cannot immediately get up may experience acute muscle deterioration due to immobility-related ischemia which may then result in permanent impairment of functional status. Both physical and psychological injury can occur as the result of a fall. Fractures of the bones of the hip, spine, legs, hand and pelvis are the most common physical injuries, while traumatic brain injuries are cited as the most common cause of fall-related deaths (CDC, 2015). Psychologically, an older adult may develop an inordinate fear of walking or standing known as basiphobia (The American Heritage Stedman's Medical Dictionary, 2015). This may result in the older adult isolating themselves socially, further limiting their mobility and activity, which has been found to actually increase their chance of falling again (CDC, 2015; Kiel, 2014; Visschedijk, Achterberg, van Balen and Hertogh, 2010).

\section{Potential Barriers to Implementation}

There are three potential barriers that must be acknowledged and addressed for successful implementation of this clinical project. The first barrier for examination includes the physiological, psychological and cognitive changes that are attendant to the normal aging 
process. The ability of an older adult patient to give and receive effective communication can be affected by age-related diminishment of auditory and visual function (Kececi \& Bulduk, 2012; Tabloski, 2010). Learning can further be impeded by age-related decline in spatial orientation, loss of sensory motor abilities, mobility, and coordination (Nevins, n.d.). It has also been found that some patients who are in the 65 years and older age group do not perceive themselves as old, do not understand that they are at an increased risk for falls, and subsequently don't believe that fall prevention education applies to them (Hughes et al., 2008; Yardley, Donovan-Hall, Francis and Todd, 2006). As a result of this, effective educational opportunities can be lost as the teaching nurse may misinterpret the patient’s apparent disinterest as a lack of comprehension. If the nurse then attempts to further re-educate the patient, the patient may become angry, blocking the way for future meaningful communication to take place (Miller, 2010). Cognitive impairments such as short-term memory loss, slower information processing, and "interference effects"- this referring to perceived discrepancies between what has been learned previously and newly offered information - are commonly encountered in the aging patient and can profoundly impact their capacity to comprehend offered education (Nevins, n.d.).

Cultural influences comprise a second barrier that must be addressed when implementing patient education. Historically, Appalachian people have been stereotypically portrayed as being disinclined to others' involvement in their healthcare practices. It has also been widely believed that Appalachian people consider health problems to be inevitable and will therefore see little point in participating in activities or behaviors to improve their physical well-being (Centers for Disease Control and Prevention, 2006). Newer studies are reporting that such commonly-held beliefs are not true. Coyne, Demian-Popescu, and Friend (2006) found that Appalachians readily appreciate that lifestyle behaviors can impact their health and will seek medical help when 
needed. It was also found that the idea of an inflexibly patriarchal decision-making social structure within Appalachian families was false. This study found that family members were typically included when decisions about health matters needed to be made. This particular finding was also supported in a review of five studies conducted by the National Institutes of Health which indicated that the Appalachian family played the most central role in health concerns (Denham, Meyer, Toborg \& Mande, 2004).

To be successful in any education effort involving the Appalachian people, one must appreciate cultural influences upon interpersonal communication. Huttlinger and Purnell (2008) noted that the Appalachian people prize self-reliance and will carefully avoid the appearance of powerlessness. These inclinations may prevent them from asking questions of their caregiver as a means to avoid embarrassment. Conversational replies with non-revelatory answers such as yes or no or overly simplified answers would not be unexpected; including responses which tell the caregiver what they think the caregiver might want to hear. To address this, Denam et al. (2014) suggested that health education discourse be concise and factual, communicating politely and non-judgmentally in both verbal and non-verbal exchanges.

The final barrier associated with patient education of the older adult is low health literacy (LHL). To address this challenge, one must understand that older adults have been found to have more limited literacy skills than others. Sudore et al. (2006) define limited literacy as 0 to $8^{\text {th }}$ grade reading level. The percentage of people over the age of 65 who have less than a high school education in West Virginia is $27.9 \%$ and in the Appalachian counties of Ohio and Kentucky, 23.9\% and 44\% respectively. Limited literacy skills will include difficulty in reading printed materials, forms, charts and also in performing quantitative tasks, all of which can be associated with LHL (Rudd, 2009; Sudore et al., 2006). It should be noted here that Sudore and 
Schillinger (2009) found that one-half of the population of the United States has LHL and patients with LHL will have difficulty participating in their care because they are unable to effectively communicate with their healthcare provider. In turn, healthcare providers often overwhelm all patients with too much information and then inadequately assess the patient's comprehension by asking such closed-ended questions as, "Do you have any questions?”, or "Do you understand?”. It is estimated that between 40 and $80 \%$ of health information that is taught is immediately forgotten and half of that which is retained is remembered incorrectly (Anderson, Dodman, Kopelman, \& Fleming, 1979; Kessels, 2003). Clearly, an effective and reinforcing intervention such as Teach-back would be helpful in addressing the patient education challenges for adults 65 and older living in Appalachia.

\section{Problem Statement}

\section{Population and Demographics}

This project will be implemented on a nursing unit in a 393 bed acute care hospital in southwestern West Virginia. In this hospital the patient population is comprised primarily of residents of the Appalachian regions of southwestern West Virginia, southeastern Ohio, and eastern Kentucky. Population percentages of people 65 years and older for the Appalachian counties of these states is $16.5 \%(\mathrm{WV}), 16.0 \%(\mathrm{OH})$ and $14.9 \%(\mathrm{KY})$ (Pollard and Jacobsen, 2015). The combined percentage of Medicare and managed Medicare patients in this hospital is 55\% (T.A. Campbell, personal communication, April, 2, 2015).

A demographic review of falls-related events reveals that within all groups, Caucasian women are at greatest risk of falling (CDC, 2015). When comparison is made based on gender, women are more likely to sustain fractures, whereas men are more likely to die from their falls (CDC, 2015). In each state, female to male gender percentages are 50.6\% /49.4\% (WV), 51.1\% 
/48.9\%(OH), and 50.8\% /49.2\% (KY) (U.S. Census Bureau, 2015). African Americans and Hispanic Americans are both less likely to suffer a fall than Caucasians, and Hispanics are reported as having the lowest death rate from falls (CDC, 2015). The populations of West Virginia and the Appalachian counties in Ohio, and Kentucky are primarily Caucasian (WV, 92.9\%, OH, 91.6\%, KY, 95.3\%) with African Americans making up 3.1\%, 4.2\% and 1.8\% of these states' counties respectively and Hispanics further accounting for less than two percent in each area (Pollard and Jacobsen, 2015). Disability among older adults has been positively correlated with increased risk for falls (Bloch, Thibaud, Duque, Rigaud \& Kermount, 2010). Further, the majority of men and women in the 65+ age group will have more than one disability and this, combined with aging-related cognitive and functional impairment, greatly increases risk for falls (Cignole, Langa, Kabeto, Tian \& Blaum, 2007; Fortin, Bravo, Hudson, Vanasse \& Lapointe, 2005). Pollard and Jacobsen (2015) report that the percentages of disabled older adults among the target population included in this project is $44.3 \%(\mathrm{WV}), 38.0 \%(\mathrm{OH})$, and $49.5 \%$ $(\mathrm{KY})$.

\section{Clinical Site: Falls Incidence, Cost and Standard of Practice}

The incidence of falls for fiscal year 2015 (October 1, 2014 - September 30, 2015) for the proposed clinical site was reported to be 575 (K. Chinn, personal communication, July 12, 2016). Haines et al. (2013) note that the cost of one fall averages $\$ 14,056$. This cost when multiplied by this number of falls for this clinical site could therefore be extrapolated to direct costs and/or potential loss of revenue of $\$ 8,082,200.00$ for the fiscal year.

To address the issue of falls, an interdisciplinary "falls team” was formed in 2009 with members included from nursing, physical therapy, pharmacy and risk management. The team initially met regularly to discuss falls data and interventions that might be successfully 
implemented. These interventions have included use of the Morse Falls Scale, bed alarms, chair alarms, sitters, low beds, mats beside the low beds, and post-fall conferences. In spite of the adoption of these measures, the rate of falls and falls with injury have not significantly declined over time. In recent years, regular meetings of the falls team have tapered off and team members primarily consists of nurses only.

At the clinical site, an ongoing general falls prevention nursing practice that antedates the formation of the falls committee is also in place to educate all patients regarding their surroundings. This includes instruction on the location and use of the nurse call button, convenient placement of the patient's commonly used belongings and asking patients to always call for assistance when getting out of bed. Within this educational interaction, patients are usually asked closed ended questions such as "do you understand?” or “do you have questions?” and this comprises the basic educational session with routinely no further assessment or patient follow-up (S. Alexander, personal communication, July $6^{\text {th }}$, 2015). Finally, research has shown that individualizing patient education is an effective intervention in the patient's selfmanagement in prevention of falls (Dinh, Clark, Bonner \& Hines, 2013). These findings are foundational for this proposed practice change.

\section{Purpose of Project}

The purpose of this project is to implement and evaluate Teach-back as a pedagogical method for delivering falls prevention education to older adults in an inpatient hospital setting. The practice change for this project is the implementation of the Teach-back patient education methodology (hereinafter referred to as Teach-back) to reduce older adult falls in the inpatient hospital setting. Teach-back is an evidence-based and simple intervention executed in a caring and nonjudgmental way, and is performed by the nurse in an environment reflecting both trust 
and respect. The nurse provides appropriate instruction and then asks the patient and/or the patient's family to repeat in their own words the instruction they have been given. The nurse can then evaluate the patient's comprehension of the teaching and may then choose to re-educate, utilizing modalities of teaching and learning that have emerged as most effective for the individual patient (Boushon et al., 2012; Sudore, 2009). It is important that a flow of ongoing feedback be established in order that the patient's comprehension can be regularly assessed by way of structured evaluation (Schillinger et al., 2003). Edgman-Levitan (2004) notes that quality and safety of hospitalization will improve when patients and families become participative partners in their own care and this tenet is a guiding principle of Teach-back.

The evidence for using Teach-back as an intervention to reduce older adults patient falls in the hospital setting is based on recommendations from national organizations concerned with healthcare quality. Most notably, the National Quality Forum (2010) included Teach-back as one of their 34 recommended practices to help improve safety for patients and to prevent errors. This recommendation was supported by The American Academy of Family Physicians, the American College of Surgeons, the American Hospital Association, the American Nurses Association and the Federation of American Hospitals. Teach-back can also be found as a recommendation in a clinical practice guideline - Prevention of Falls (Acute Care) - from the Institute for Clinical Systems Improvement (Degelau et al., 2012).

For this project, Teach-back will be implemented using principles from the, "Always Use Teach-back!” program (“Always Use Teach-back!, 2015). This program was created partially as part of the Picker Institute's Always Events Program (2012) and was funded by grants from the Picker Institute and the Des Moines University Iowa Osteopathic Education and Research Program by UnityPoint Health (Institute for Healthcare Improvement [IHI] 2015). This program 
is recommended by the IHI, the Agency for Healthcare Research and Quality (2014) and The Joint Commission (2007). The tools used from this program were the Observation Tool (Appendix A) and the 45 minute interactive video. Patients received education based upon recommendations from the "How-to Guide: Reducing Patient Injuries from Falls” (Appendix B). This guide was developed as a "Transforming Care at the Bedside initiative (TCAB)", which resulted from the combined efforts of the Robert Wood Johnson Foundation and the IHI to improve quality and safety for patients (Boushon, Nielson, Quigley, Rutherford, Taylor, Shannon \& Rita, 2012).

\section{Significance of Proposed Project}

The problem of falls in a hospital setting has been of concern for almost 50 years (Currie, 2008). For hospitals, there is currently heightened interest and emphasis being placed on the prevention of falls. This is primarily because the Centers for Medicare and Medicaid have deemed inpatient falls as largely preventable events and have stopped reimbursing hospitals for treatment costs related to such falls (CMS, 2009). Most private payers are following suit and the number of falls-related lawsuits have increased correspondingly (ERCI, 2009). On a national level if the problem with falls is not successfully addressed, the payment for the care of these patients will continue to grow into the billions of dollars and the societal debt burden could become insupportable. (Stevens, Corso, Finklestein \& Miller, 2006).

For the older adult patient, a fall while in the hospital can result in physical injuries that require long term recovery or cause irreversible injury and possibly even death. Psychologically, the patient who suffers a fall may experience social isolation, depression and feelings of helplessness.(Hsu, 2004; World Health Organization [WHO] 2007). A fall for a patient while in the hospital can sometimes mean insurmountable medical costs, associated not only with 
hospitalization but also to provide care needed after hospitalization. These costs include medical office visits, skilled nursing or home health care. It is estimated that 20 to $30 \%$ of geriatric falls are severe enough that the patient can no longer live alone incurring significant costs related to long term in-home or even institutional care. Further, as many as one-third of geriatric patients, experiencing such falls when hospitalized will require post-hospitalization assistance and over one-half of those will continue to require help for at least six months. (Schiller, Kramarow and Dey, 2007; Stevens et al., 2006). Literature has shown that Teach-back is a simple, evidencebased strategy that has produced quantifiable and dramatically positive results for both healthcare institutions and patients (Dinh, Clark, Bonner \& Hines, 2013; LaBresh,-Jarette \& Lux, 2011).

\section{Literature Review and Synthesis}

\section{Search Strategy}

The purpose of this literature review was to discover pertinent research that examined the effectiveness of the Teach-back patient education methodology, both as a stand-alone intervention or in combination with other interventions. The exploration of the literature included a computerized search of the Cochrane Library, JSTOR, PubMed, MEDLINE and CINAHL. Search restrictions included English language only, the inclusion of an abstract, peer reviewed journals and an eleven year time frame from January 2005 through May of 2016. Keywords included were Teach-back, falls, inpatient, older adults, nursing, patient education, hospital, and falls prevention. Various combinations of the keywords were used which resulted in 757 total hits. A hand search and review of reference lists resulted in 8 additional studies and 1 unpublished study being identified as possibly relevant. Only one study was found that specifically addressed the impact of Teach-back on patient falls. The search did however reveal 
other research studies that examined the impact of Teach-back on the comprehension and retention of patient education and the effectiveness of Teach-back on various patient outcomes. The titles of all the articles were reviewed for possible relevance to the clinical project. Articles were excluded if there was no reference to Teach-back or patient education in the title. This resulted in 422 articles being excluded leaving 344 studies to be screened. Abstracts of these studies were evaluated for relevance to the efficacy of Teach-back, and the absence of which resulted in the elimination of 318 of these studies. The remaining 26 studies were reviewed in their entirety. Four studies were excluded as they were actually performance improvement initiatives; one study focused on perceptions of the nurse about Teach-back; two studies focused on physician use of Teach-back in their offices; one study was not based on research but was actually a narrative and one study was a systematic review proposal.

The remaining 14 studies selected for this review include one systematic review, four randomized control trials, one non-randomized controlled trial, two prospective cohort studies and six prospective observational studies. The systematic review, randomized control trials, nonrandomized control trial and prospective observational cohort studies were evaluated using tools from the Scottish Intercollegiate Guideline Network (2015) (Appendix C). The prospective observational studies were evaluated using the Larrabee form for quantitative appraisal (Larrabee, 2009) (Appendix D). The studies were separated into two categories: those studies that primarily assessed comprehension and retention of information provided via the Teach-back methodology and those studies that assessed the impact of information provided via Teach-back on various patient outcomes. 


\section{Findings}

The studies of each category are listed in order of strength of scientific evidence as described by Melnyk \& Fineout-Overholt (2011, p. 12) (Appendix E) and are summarized in Tables 2 and 3, found in Appendix F. A flow diagram of the search strategy can be found in Appendix G.

\section{Synthesis}

The results of this literature search yielded only one study that was directly related to patient falls. The other studies that were included in the review were divided into two sections, first those studies that purely measured comprehension and retention of information provided by Teach-back and secondly those studies that measured the impact of Teach-back on specific patient outcomes. Heterogeneity of findings was found to exist in both categories. Eight studies were devoted to measuring the impact of Teach-back on the comprehension and retention of information of patient education by patients. Investigators in three studies concluded that Teachback had a positive impact on comprehension and retention of information (Griffey et al, 2015; Howie-Esquivel et al., 2014; Howie-Esquivel et al., 2011). The findings of only one study did not support the use of Teach-back (Kandula et al., 2011) and data from four studies indicated mixed results (Gross et al., 2013; Kripalani et al., 2008; Wilson et al., 2012; Wilson et al., 2008). Six studies measured the impact of Teach-back on specific patient outcomes. The results of four studies indicated a positive impact of Teach-back on patient outcomes (Bates et al., 2014; Dantic, 2014; Negarandeh et al., 2013; White et al., 2013). In the patient outcome category, only one study conducted by Hyrkas and Wiggins (2014) did not find that Teach-back influenced patient outcomes and one study conducted by Quigley et al. (2009) indicated mixed results. 


\section{Theoretical Framework}

The theory used to support this practice system change is Dorothea Orem’s Self- Care Deficit Nursing Theory (SCDNT). Orem (1995) describes self-care as "learned, goal-directed activity of individuals. It is behavior that exists in concrete life situations directed by persons to self or to the environment to regulate factors that affect their own development and functioning in the interests of life, health, or well-being” (p.435). The overarching theme of this theory is that individuals want to take care of themselves, but when they are unable to do this, the nurse and patient can establish a relationship and work together to return the patient to a state where they can practice self-care again if possible (Nursing Theory, 2013). The SCDNT is comprised of three interrelated theories: the Theory of Self-Care, the Theory of Self-Care Deficit, and the Theory of Nursing Systems (Orem, 1995).

\section{Theory of Self-Care}

Self-care, self-care agency, therapeutic self-care, and self-care requisites are the main constructs in The Theory of Self-Care. Orem (1995) describes self-care as deliberate actions performed by individuals over time creating “action systems” which are used to sustain life, health and well-being. It is these action systems that help an individual maintain self-care when conditions such as protection from environmental hazards present themselves. Self-care agency is explained as an ability to "engage in self-care, conditioned by age, developmental state, life experience, socio-cultural orientation, health, and available resources” (Orem, 1995, p.175).

Orem further describes therapeutic self-care as actions performed over time in totality that enable an individual to meet self-care requisites by means that have been proven to be reliable and valid. These self-care requisites are divided into the categories of universal, developmental, and health deviation self-care requisites. Universal self-care requisites are basic requirements to 
sustain human life such as air, water and food as well as prevention of hazards that could threaten one's well-being. Developmental requisites are how universal self-care requisites are learned through experience or developmental processes. Finally, health deviation self-care requisites are needed when illness, injury or disease occur. These include seeking medical assistance, following specific treatment plans and making adjustments to any changes that may occur as a result of a medical condition (Orem, 1995).

\section{Theory of Self-Care Deficit}

Orem (1995) describes the Theory of Self-Care Deficit as the reasons why individuals require nursing care. In this theory, Orem presupposes that age, developmental state, sociocultural influences, life experiences, educability and a person's knowing what to do under existing circumstances impact the level of quality and comprehensiveness of their ability to engage in self-care. These factors are a consideration for the nurse as they help the patient meet their self-care needs. The five specific ways a nurse can help a patient are acting or doing for others, guiding others, supporting another, providing an environment promoting personal development in relation to meeting future demands and teaching others (Orem, 1997).

\section{Theory of Nursing Systems}

In the Theory of Nursing Systems, Orem (1995) describes how the nurse will help the patient with their self-care needs: how either the patient can do it or how both nurse and patient together can meet the self-care needs of the patient. (Nursing Theory, 2013). The Theory of Nursing Systems (TNS) incorporates the Theory of Self-Care (TS-C) and the Theory of SelfCare Deficit (TS-CD). The processes of how one takes care of one's self is outlined in TS-C and TS-CD and describes what is to be done when nursing care is needed. The Theory of Nursing Systems describes the nature of services provided by the nurse to the patient through "nursing 
systems” and “nursing agency” (Theory Based Nursing Practice, 2014). Nursing systems are defined as the actions performed by the nurse in conjunction with the patient so the patient can meet therapeutic self-care demands and help regulate their own self-care agency. Nursing agency is comprised of interpersonal, professional, technological and critical-thinking skills, learned over time and in life experience that help the nurse understand and accept the patient's culture and values in order to effectively treat patients with empathy and connect with them on a deeper level (Theory Based Nursing Practice, 2014). Orem (1995) notes that nursing systems can be wholly compensatory (no patient participation), partly compensatory, or supportive-educative, where the patient is capable of adequate self-care (pp. 308-311).

\section{Project}

\section{Project Design}

A quasi-experimental design was used to evaluate Teach-back as a pedagogical method for delivering falls prevention education to decrease falls in patients 65 years of age and older in an inpatient hospital unit. The project was implemented on a nursing unit in a 393 bed acute care hospital in southwestern West Virginia. Patients were eligible for inclusion in the project if they were 65 years of age or older. Patients were excluded from the project if they could not verbalize who they were and/or where they were, if they were under physical or chemical restraint, required a 1:1 sitter, could not conduct a conversation or could not give written consent to participate in the project. The secondary investigator of this project served as the project coordinator. 


\section{Project Procedure}

Various meetings were held with the nursing staff to explain the project and to ask for consent for participation. Eleven nurses consented to participate (27.5\% of the staff). One nurse transferred to another unit and two dropped out of the project thus reducing the participation percentage to $20 \%$. Once consent was obtained from the nursing staff, pre-intervention data collection began immediately. Nurses were observed for presentation of falls prevention patient education to patients until a sample of 120 patients was reached. Patients were approached to obtain consent to review their patient teaching documents. Once permission was obtained the documents were reviewed to determine if falls prevention education was documented. Nurses were then provided with education about providing falls prevention education to patients using Teach-back. Once the education was completed, nurses were observed for the use of Teach-back to provide falls prevention education until a sample of 120 patients was reached. Patients were approached to obtain consent to review their patient teaching documents. Once permission was obtained the documents were reviewed to determine if there was evidence of falls prevention education using Teach-back. The falls and falls with injury data for February, March, and April of 2015 and 2016 were obtained from the Risk Management Department.

\section{Strength, Weaknesses, Opportunities, Threats}

The key stakeholders in this project were the front-line registered nursing staff, nursing management, risk management, administration, together with patients and their families. The grid below details specific strengths, weaknesses, opportunities and possible threats (SWOT) associated with implementing the Teach-back educational methodology. 


\begin{tabular}{|c|c|}
\hline $\begin{array}{l}\text { Strengths } \\
\text { Supportive risk management department } \\
\text { Falls team is already in place } \\
\text { Implementation materials are free } \\
\text { Program is easy to teach and learn } \\
\text { Support from administration and nursing management }\end{array}$ & $\begin{array}{l}\text { Opportunities } \\
\text { Reduction in fall rate thereby improving patient safety } \\
\text { Reduction in lawsuits } \\
\text { Improved reimbursement due to eliminating or } \\
\text { reducing the "never event" of falls }\end{array}$ \\
\hline $\begin{array}{l}\text { Weaknesses } \\
\text { Teaching a large number of registered nurses and staff } \\
\text { (Time, Money and Human Resources needed to teach) } \\
\text { No one in charge of patient teaching. } \\
\text { Pushback from nursing staff ("one more thing to do") }\end{array}$ & $\begin{array}{l}\text { Threats } \\
\text { Reduced volume } \mathrm{d} / \mathrm{t} \text { poor community perception } \\
\text { Unplanned readmission resulting in reduced } \\
\text { reimbursement } \\
\text { Patient injury resulting in increased costs and lawsuits. }\end{array}$ \\
\hline
\end{tabular}

The analysis of the SWOT exercise reveals that the strengths of the project could result in opportunities that improve patient safety, reduce costs and improve reimbursement. Addressing and eliminating identified threats also lends support to a possible future implementation of the program. The weaknesses that were identified provide challenges but these can be directly addressed with strong change management strategy.

\section{Resources}

Cost for implementation of this project was $\$ 336.00$. Eight nurses were educated for one hour. They were paid at time and one-half their average hourly rate which is approximately $\$ 42.00 / \mathrm{hr}$. Computers, computer time, and any photocopying of documents used in the project were provided by the institution at no cost. The “Always Use Teach-back!” program is available online and free for public use.

\section{Congruence of Organization's Strategic Plan to the Clinical Project.}

This project is congruent with the organization's strategic plan, which describes its goals of providing the highest quality of care, expanding services, and the forging of strategic partnerships with other providers and health care facilities throughout the institution's primary and secondary markets. The goal of providing the highest quality of care directly relates to this clinical project which is further integrated when viewed against the backdrop of the values of the 
organization. The first letter of each of the values of the organization spell out the acronym, CHRIST: Compassion is demonstrated in concern for the suffering of the older adult patients that fall, particularly those suffering injury; Hospitality is established in the project's design to provide a more safe environment for the patient; Reverence is demonstrated in the respect accorded personally to the patient, inherent in the project's aim of enhanced safety; Interdependence is reflected singularly in the construct of an educational tool which owes its effectiveness to a structured interaction between patient and care provider; Stewardship is reflected in the fiscal savings made possible through achieving cost reduction for both the patient and institution; and Trust is found in the relationship between nurse and patient in this attempt to provide a more safe and comfortable hospital stay. These values can be viewed as tangible expression of the organization's core belief that each individual is worthy of the highest standards of care within a safe environment.

\section{Evidence of Key Site Support}

Permission for implementation of this project was obtained from the Chief Operating Officer. (Appendix H)

\section{Ethical Considerations}

The protocol was approved by the West Virginia University and the Marshall University Institutional Review Boards (Appendix I). Informed consent was obtained from all participants in the study. Confidentiality of the participants has been maintained. The project coordinator has sole access to all pertinent documents which are kept locked in a storage cabinet. 


\section{Project Objectives}

Objective 1: To increase the use and documentation of a validated patient education methodology by registered nurses to decrease falls in patients 65 years of age and older in a specific hospital unit.

\section{Evaluation:}

Process Measure: Observation of nurses providing falls prevention education given both before and after Teach-back education for the nursing staff.

Tool: “Always Use Teach-back!” Observation Tool with modifications. Audit of patient education forms.

Data Collection and Analysis Procedures: Prospective data collection was completed prior to and following Teach-back education for the nursing staff. Data analysis was completed using the SPSS statistical package version 23. An independent samples t-test was conducted to compare the ages of patients in the two groups. A Chi-square test for independence (with Yates Continuity Correction) was conducted to determine if a significant association existed between the preintervention and post-intervention groups and gender. Chi-square tests for independence (with Yates Continuity Correction) were run to determine if there was an association between the independent variable (Teach-back education for the nursing staff) and the dependent variables which included using a caring tone of voice and attitude, displaying comfortable body language, using plain language, providing falls prevention patient education using Teach-back, using openended questions, avoiding using yes or no questions, taking responsibility for making sure instructions were clear, explaining instructions again if patients could not Teach-back and documenting the use of Teach-back. 


\section{Results}

Demographics: There were 240 patients included in the sample for objective one. The mean age of the sample was $76.26(S D=7.91)$ with a range of 65 to 103 years of age. Females comprised the largest percentage of the sample (60.4\%). The total sample consisted of 120 patients in the pre-intervention group (group one) and 120 patients in the post-intervention group (group two). The mean age of patients in the pre-intervention group was $77.33(S D=7.93$ ) with a range of 65 years of age to 97 years of age. A majority of the sample was female (69.2\%). The mean age for the post-intervention group was $75.20(S D=7.799)$. The range of ages for the postintervention group was 65 to 103 with females once again predominant in the sample (51.7\%).

The results of the independent samples t-test indicated that there was a significant difference in ages between the pre-intervention group $(M=77.32, S D=7.927)$ and the postintervention group $(M=75.2, S D=7.798)$; $\mathrm{t}(238)=(2.093), p=.037$, two-tailed. The magnitude of the differences in the means (mean difference $=2.125,95 \%$ CI:.1252 to 4.124) was very small (eta squared .008). With regard to gender, the results of the Chi-square test for independence indicated a significant association existed between the pre-intervention and postintervention groups with more women being in group one than in group two, $\chi 2(1, n=240)=$ 6.969, $p=.008, p h i=-.179$.

Use and documentation of Teach-back: The results of the Chi-square tests for independence (with Yates Continuity Correction) to determine if an association existed between the independent variable and the dependent variables are found in Table I. 


\section{Table 1}

Summary of Scores from the “Always Use Teach-back!” Observation Tool

\begin{tabular}{|c|c|c|c|c|c|c|}
\hline Variable & $\begin{array}{l}\text { Pre- } \\
\text { education }\end{array}$ & $\begin{array}{l}\text { Post- } \\
\text { education }\end{array}$ & $\begin{array}{l}\text { Chi- } \\
\text { Square }\end{array}$ & $d f$ & $\begin{array}{l}p \\
\text { value }\end{array}$ & phi \\
\hline Demonstrates a caring attitude & & & & & 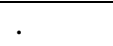 & \\
\hline Yes & $50.5 \%(112)$ & $49.5 \%(110)$ & & & & \\
\hline No & $44.4 \%(8)$ & $55.6 \%(10)$ & .060 & 1 & .806 & .032 \\
\hline \multicolumn{7}{|l|}{ Uses comfortable body language } \\
\hline Yes & $50.7 \%$ (111) & 49.3\% (108) & & & & \\
\hline No & $42.9 \%(9)$ & $57.1 \%(12)$ & 209 & 1 & .648 & 044 \\
\hline \multicolumn{7}{|l|}{ Uses plain language } \\
\hline Yes & $50.2 \%(114)$ & $49.8 \%(113)$ & . & & & \\
\hline No & $46.2 \%(6)$ & $53.8 \%(7)$ & 000 & 1 & 1.00 & .018 \\
\hline \multicolumn{7}{|l|}{ Uses Teach-back } \\
\hline Yes & $0.00 \%(0)$ & $100 \%(109)$ & & & & \\
\hline No & $91.6 \%(120)$ & $84 \%(11)$ & 196.047 & 1 & 0.00 & -.912 \\
\hline \multicolumn{7}{|l|}{ Uses open-ended questions } \\
\hline Yes & $46.1(95)$ & $53.9 \%(111)$ & & & & \\
\hline No & 73.5\% (25) & $26.5 \%$ (9) & 7.710 & 1 & 005 & -.191 \\
\hline \multicolumn{7}{|l|}{ Avoids using yes or no questions } \\
\hline Yes & $45.6 \%(93)$ & $54.4 \%(111)$ & & & & \\
\hline No & $75 \%(27)$ & $25 \%(9)$ & .944 & 1 & .002 & -.210 \\
\hline \multicolumn{7}{|l|}{ Takes responsibility for making } \\
\hline Yes & $6.0 \%(7)$ & $94 \%(109)$ & & & & \\
\hline No & 91.9\% (113) & $8.9 \%(11)$ & 173.593 & 1 & .000 & -.850 \\
\hline \multicolumn{7}{|l|}{$\begin{array}{l}\text { Explains instructions again if } \\
\text { patient unable to do Teach-back }\end{array}$} \\
\hline Yes & $53.8 \%(120)$ & $46.2 \%(103)$ & & & & \\
\hline No & $0 \%(0)$ & $8.9 \%(11)$ & 16.207 & 1 & .000 & .276 \\
\hline \multicolumn{7}{|l|}{ Documents Teach-back } \\
\hline Yes & $0 \%(0)$ & $100 \%(107)$ & 189.491 & 1 & .000 & -.897 \\
\hline No & $120(90.2 \%)$ & $9.8 \%(13)$ & & & & \\
\hline
\end{tabular}

Note: Pre-intervention group $\mathrm{n}=120$. Post-education group $\mathrm{n}=120 . p<.05$ 
Objective 2: To decrease the rate of falls and falls with injury per 1000 patient days in patients 65 years of age and older in a specific hospital unit through implementation of the Teach-back patient education methodology.

\section{Evaluation:}

Outcomes measure: Rate of falls and falls with injury per 1000 patient days before and after patient education using Teach-back regarding falls prevention. Number of repeat falls before and after patient education using Teachback.

Level of severity of injury before and after patient education using Teach-back.

Tool: Incident reports filed for falls and falls with injury.

Data collection and analysis procedures: Retrospective data collection was used to obtain baseline data for falls and falls with injury for February, March, and April of 2015. Prospective data were collected to assess current falls and falls with injury for February, March, and April of 2016. Data analysis was completed using the SPSS statistical package version 23. An independent samples t-test was conducted to compare the ages of patients in the preeducation (group one; February, March, and April of 2015) and the post-education group (group two; February, March, and April of 2016). A Chi-square test for independence (with Yates Continuity Correction) was run to determine if an association existed between group one and group two and gender. Mann-Whitney U Tests were conducted to determine the difference in the number of repeat fallers between group one and group two and to determine the difference in falls with injury classification between group one and group two. An independent samples t-test was conducted to compare fall rates per 1000 patient days and for falls rate with injury per 1000 
patient days in timeframe one (February, March, April 2015) and timeframe 2 (February, March, April 2016).

\section{Results:}

Demographics: The sample for goal two was comprised of 28 patients 65 and older who experienced at least one fall during their hospitalization. The mean age of the sample was 77.21 $(S D=8.723)$ with a range of 65 to 103 years of age. Females comprised the majority of the sample (57.1\%). Twenty-one patients fell only once (75\%), six fell twice (21.4\%) and one fell three times (3.6\%) resulting in a total of 36 falls. Of the 36 falls, 24 resulted in no harm (57.1\%) and 12 resulted moderate harm (42.9\%), which is defined as a harm that resulted in suturing, application of steri-strips or skin glue, splinting, or muscle/joint strain (National Database of Nursing Quality Indicators, 2014).

The mean age of group one was $78.9(S D=8.564)$ with a range of 66 years of age to 103 years of age. There were a total of 20 patients in group one of which ten were female and ten were male. Of the 20 patients, 16 (80\%) fell only once, three (15\%) fell twice and one patient (5.0\%) fell three times for a total of 25 falls. Of these, 14 (56\%) were rated as no harm and 11 (44\%) were rated as moderate harm.

The mean age of group two was $73.0(S D=8.124)$ with a range of 65 years of age to 91 years of age. Females comprised the majority of the sample (75\%). There were a total of eight patients in group two. Of these eight patients, five patients (62.5\%) fell once, and three patients (37.5\%) fell twice for a total of 11 falls. Of these, nine (81.8\%) were rated as no harm and two (18.2\%) were rated as moderate harm. 
The results of the independent samples t-test conducted to compare the ages of patients in the two groups revealed there was no significant difference in ages between group one ( $M=$ $78.9, S D=8.564)$ and group two $(M=73.0, S D=8.124)$; $(26)=(1.669), p=.107$, two-tailed. The magnitude of the differences in the means (mean difference $=5.90,95 \%$ CI:1.364 to 13.164 ) was small (eta squared .038). Results of the Chi-square test for independence (with Yates Continuity Correction) ran to determine if there was an association of gender between group one and group two revealed there was no significant association $\chi 2(1, n=28)=.616, p=.432$, phi $=$ .228. The Mann-Whitney U Test results indicated there was no statistical difference between group one ( $M d=1.0, n=20)$ and group two $(M d=1.0, n=8), U=67.5, z=-.843, p=.399, \mathrm{r}$ $=0.15$ with regard to the number of repeat fallers, however there was a statistical difference in falls with injury classification between group one $(M d=3, \mathrm{n}=25)$ and group two $(M d=1, \mathrm{n}=$ 11), $U=46.000, z=-2.016, p=.044, r=0.34$.

Falls per 1000 patient days: To calculate falls per 1000 patient days (herein referred to as patient falls) aggregate patient days and aggregate falls must be reported by month thus the sample is changed from groups to timeframes. The sample was comprised of total falls per month for three months for two separate time periods: timeframe one $(n=3$ : February, March, and April 2015) and timeframe two ( $\mathrm{n}=3$ : February, March, and April 2016). In timeframe one, patients had not received Teach-back education. Twenty patients fell for a total of 25 falls (Five falls in February, 14 falls in March, and six falls in April). The number of patient days for timeframe one were 870, 895, and 919 respectively. Using the formula provided by the Agency for Healthcare Research and Quality [AHRQ (2014), Appendix J], patient falls for timeframe one were calculated to be $5.78,16.0$, and 6.53 respectively. 
In timeframe two (February, March, and April of 2016) patients had received falls prevention education using Teach-back. Eight patients fell resulting in a total of 11 falls (three falls in February, three falls in March, and five falls in April). The number of patient days for timeframe two were 793, 818, and 871 respectively. Using the formula provided by the Agency for Healthcare Research and Quality to calculate falls per 1000 patient days, patient falls for February, March, and April 2016 were calculated to be 3.78, 3.66, and 5.74 respectively.

The results of the independent samples t-test revealed no significant difference in fall rates between timeframe one $(M=9.4333, \mathrm{SD}=5.69892)$ and timeframe two $(M=4.3933, S D=$ 1.16779); $\mathrm{t}(2.168)=(1.501), p=.263$, two-tailed. The magnitude of the differences in the means (mean difference $=5.040,95 \%$ CI:-8.391 to 18.471) was small (eta squared .023 ).

Falls with injury per 1000 patient days: To calculate falls with injury per 1000 patient days (herein referred to as falls with injury) aggregate patient days and aggregate falls with injury must be reported by month thus the sample is changed from groups to timeframes. The sample was comprised of total falls per month for three months for two separate time periods: timeframe one ( $\mathrm{n}=3$ : February, March, and April 2015) and timeframe two ( $\mathrm{n}=3$ : February, March, and April 2016). In timeframe one, patients had not received Teach-back education. Twenty-five falls occurred in timeframe one of which 11 resulted in injury (two falls in February, seven falls in March, two falls in April). The number of patient days for timeframe one were 870, 895, and 919 respectively. Using the formula provided by the Agency for Healthcare Research and Quality (2013) for calculating the rate of falls with injury per 1000 patient day, patient falls with injury for timeframe one were calculated to be $2.30,7.82$, and 2.18 respectively. 
In timeframe two (February, March, and April of 2016) patients had received falls prevention education using Teach-back. Eight patients fell resulting in a total of 11 falls of which two resulted in injury (one fall with injury in February, one fall with injury in April). The number of patient days for timeframe two were 793, 818, and 871 respectively. Using the formula provided by the Agency for Healthcare Research and Quality patient falls for February, March, and April 2016 were calculated to be 1.26, 0.0, and 1.14 respectively.

Results of the independent samples t-test revealed no significant difference in fall with injury rates between timeframe one $(M=4.1000, \mathrm{SD}=3.22217)$ and timeframe two $(M=.8000$, $S D=.69541) ; \mathrm{t}(2.186)=(1.734), p=.214$, two-tailed. The magnitude of the differences in the means (mean difference $=3.30,95 \%$ CI:-4.256 to 10.856) was small (eta squared .025 ).

\section{Discussion}

\section{Objective one}

The sample was divided between patients who had not received falls prevention education using Teach-back: group one (pre-intervention) and patients who had received education group 2 (post-intervention). The independent t-test indicated a significant difference in the ages between groups although the magnitude of the effect was small. The pre-intervention group mean age was 77.33 and the post-intervention group mean was 75.21. Both mean ages were older than the most populous age range for people 65 and older in West Virginia, Ohio, and Kentucky which is 7074 (United Census Bureau, 2015). In both groups, women comprised the majority of the sample. These findings are reflective of the percentage of women to men in West Virginia (50.6\% /49.4\%), Ohio (51.1\% /48.9\%) and Kentucky (50.8\% /49.2\%) (U.S. Census Bureau, 2015). 
The analysis of the data indicated no association existed between the independent variable (Teach-back education for the nursing staff) and the dependent variables of using a caring tone of voice and attitude, displaying comfortable body language, and using plain language. Statistically significant associations did exist between the independent variable and the dependent variables of providing falls prevention patient education using Teach-back, using open-ended questions, avoiding using yes or no questions, taking responsibility for making sure instructions were clear, explaining instructions again if patients could not Teach-back and documenting the use of Teachback. The absence of an association between the independent variable and the first three dependent variables can be considered a positive finding as nurses should be already be using a caring tone of voice and attitude, displaying comfortable body language and using plain language when interacting with their patients. Analysis of the data indicated improvement in providing falls prevention patient education using Teach-back, using open-ended questions, avoiding using yes or no questions, taking responsibility for making sure instructions were clear, explaining instructions again if patients could not Teach-back and documenting the use of Teach-back. These findings are important for several reasons including the expansion and integration of evidencebased practice (EBP) into nursing care. The adoption of EBP by nurses has been challenging and slow but remains a worthwhile goal as research has shown that EBP can reduce length of stay and readmissions for patients (Caldwell, 2014). In this clinical setting, the education patients receive is valuable but the delivery of the information is mechanical, unilateral, and assumptions are made that the patient understands what they have been taught. Alspach (2006) notes that "EBP "helps approximate the edges that lie among and between ritualistic practices, habitual approaches, personal preferences, anecdotal experiences, empirical data, and unequivocal statistical significance to support current nursing practice “ (p. 11). Teach-back is a perfect 
example of how the nurse can use the best evidence available, combine that evidence with their own expertise and integrate the preferences and values of the patient into their plan for patient education.

\section{Objective Two}

The sample was divided between patients who had not received falls prevention education using Teach-back: group one (pre-intervention; February, March, and April 2015) and patients who had received education group 2 (post-intervention; February, March, and April 2016). Analysis of the data indicated that significant difference in the ages between groups although the magnitude of the effect was small. The group one mean age was 78.9 and the mean age for group two was 73. The group one mean age exceeded the most populous age range (70-74) for West Virginia, Ohio and Kentucky (United Census Bureau, 2015). Group one was comprised of more women which is consistent with the finding that women fall more frequently than men (CDC, 2015). Conversely, the percentage of men to women in group two was 50/50.

A raw number comparison of falls, falls with injury, repeat fallers, and level of injury revealed that during the 2016 timeframe there were decreases in each category however when statistical analysis was completed, only higher level of injury was reported as statistically significant. An adjustment for patient volume was completed by measuring fall rate and fall rate with injury per 1000 patient days. Analysis of the data indicated that there was no significant difference in falls or falls with injury per 1000 patient days between the two timeframes. This finding is somewhat consistent with the study by Quigley et al. (2009) who found only a slight decrease in falls per 1000 patient days and no change in falls with injury with the use of Teachback for falls prevention for hospitalized patients. The disparity between the raw number scores

and the rate of falls and falls rate with injury per 1000 days may at least be partially explainable 
by the wide fluctuations in volumes between the two time periods. There was a $9.26 \%$ decrease in volume between February 2015 and 2016, an 8.99\% decrease between March 2015 and 2016, and a $5.36 \%$ decrease between April 2015 and 2016. Volume could therefore be a legitimate reason for the disparity. Another factor to consider is that $\mathrm{p}$ values do not measure effect size (Reinhart, 2015). In both falls and falls with injury per 1000 patient days, the effect size was noted to be small so although there was no significant difference between groups, the strength of the finding is minimalized.

\section{Support of Theoretical Model}

Dorothea Orem's Self- Care Deficit Nursing Theory (SCDNT) was the framework utilized to guide this practice change. There is a direct link between the SCDNT to the growing movement in healthcare that recognizes that involvement in one’s own care is a primal component in improving quality and safety (Longtin et al., 2010). Teach-back provides patients with the opportunity to be participants in their care by actively engaging in a plan with the nurse to keep their environment safe and reduce the chances that an injury will occur from a fall. Orem (1995) explains that self-care at its most basic level involves individuals attending to basic life

needs (requisites), such as avoiding environmental hazards which could lead to deviations in selfcare requisites. Patients are not familiar with the hospital environment and therefore don't know all of the hazards that exist. To avoid a fall, it is incumbent on the nurse to engage patients in the evidence-based Teach-back patient education methodology to raise the patient's awareness and thereby mitigate the risks that can be found in the patient's environment.

The SCDNT outlines the factors that influence an individual's ability to engage in selfcare. These include age, sociocultural effects as well as level of education and availability of knowledge of what is necessary to continue to engage in self-care behaviors. Understanding and 
recognizing these factors helps nurses navigate through the challenges of working with older Appalachian patients who may have low health literacy and low educational levels together with the normal challenges associated with aging. Teach-back helps a nurse evaluate the ongoing educational needs of patients whose ability or willingness to learn is impacted by these factors. From this evaluation, the nurse can use Teach-back to reshape the educational plan with the patient. This practice is well outlined in the SCDNT. Orem (1995) speaks to the independence of patients as they seek to meet their needs but she also addresses the processes needed when the patient cannot accomplish this themselves and the nurse must help them. Teach-back is a perfect example of helping patients achieve their self-care needs through activities such as fall prevention actions that can prevent harm that may have long-lasting negative consequences, further preventing the patient from performing activities that regulate both mental and physical health.

\section{Summary}

\section{Weaknesses and Limitations}

There were several limitations associated with this project. Non-probability sampling was used therefore findings from this project cannot reliably be generalized to the total population of hospitalized older adults. Inter-rater reliability was not conducted for the "Always Use Teachback!” observation tool therefore the subjectivity of the project coordinator and staff introduced the chance for bias. The nursing unit experienced an unexpected high percentage of registered nurse turnover during the project. The turnover resulted in the registered nursing staff working with less staff members which resulted in participating staff feeling rushed as they engaged in patient teaching. The propensity for participants to change their behavior while being observed in a research study, known as The Hawthorne Effect, was also a consideration. McCambridge, Witton \& Elbourne (2014) conducted a systematic review that summarized and evaluated the 
strength of evidence on the Hawthorne effect. Their review included eight randomized controlled trials, five quasi-experimental studies and six observational evaluations. They concluded that there is some evidence of the Hawthorne Effect in some of the research studies although it could not be determined as under what circumstance it occurred, why it occurred or how great the magnitudes were. Finally, confounding variables could not be controlled for. These confounding variables included medications, nutritional deficiencies and age related vision or hearing deficits, use of low-beds with mats and chair alarm usage.

\section{Recommendations}

A recommendation for the medical center is to restructure the current falls team by establishing a team of interprofessional staff (nursing, physical therapy, dietary, pharmacy, housekeeping, and risk management) and leaders to develop and oversee a comprehensive falls prevention program. This new team can offer various perspectives of the falls issue and infuse a renewed sense of urgency to falls reduction.

Building on the establishment of an interprofessional falls team, another recommendation is to develop the program using evidence-based clinical practice guidelines of which Teach-back is a featured intervention. The hospital has implemented various falls prevention measures such as low-beds, chair and bed alarms, and the Morris Falls Scale to identify high-risk patients. These interventions have value but have been instituted independently as opposed to being part of a greater strategic plan with no measurable reduction in patient falls.

To determine the success of the falls prevention program, measurement of the falls rate and falls rate with injury must be a top priority for the new falls team. Robust, stratified data collection should replace the current basic program in order for the team to analyze the data to 
look for trends and thereby evaluate the efficacy of new interventions. Currently, unit specific data are not shared by units nor is it shared with the staff. Increased transparency of findings may increase the "buy-in" of staff to an ongoing falls prevention program.

A hospital-wide Teach-back initiative should be planned and implemented by the Organizational and Development Department not only for falls prevention education but for all education. Patients who become partners in their own care will improve the overall quality and safety of their hospitalization. This becomes a serious challenge when patients have become overwhelmed with the amount of information they have been given and if there are low healthliteracy issues. Teach-back provides a viable avenue for the nurse to improve communication between themselves and the patient and it provides a mechanism for the nurse to assess and validate a patient's and/or family's understanding of fall and injury risk teaching.

\section{Future Work}

A comprehensive review of the literature revealed very limited research related to the efficacy of Teach-back and the findings from those studies are heterogeneous in nature. The first objective of this project was to increase the use and documentation of the Teach-back methodology. This objective was achieved but a large question remains: "Will this intervention become an accepted part of the culture"? Both established and innovative interventions are not enough to guarantee successful integration into organizational cultures, therefore more research is needed to focus on the development and testing of integration strategies that result in widespread adoption and implementation by the staff of falls prevention interventions like Teach-back. 
The second objective of reducing the falls and falls rate with injury per 1000 patient days was not met. Given that Teach-back is a highly recommended intervention by numerous well respected agencies concerned with quality and safety, consideration should be given to extending this study over a longer period of time and increasing the size of the sample. The impact of Teach-back should also be studied as part of a multi-modal program for falls prevention within the organization as individual interventions to reduce falls and falls with injury have been largely unsuccessful.

\section{Attainment of DNP Essentials}

\section{Scientific Underpinnings for Practice}

Through my research of literature related to Teach-back, I was able to combine knowledge from nursing science with other sciences to develop my project. I was able to gain a broader understanding of the health phenomena of falls in the older adult and apply what I had learned about the efficacy of Teach-back as a possible intervention to successfully reduce falls in an acute care setting.

\section{Organizational and Systems Leadership for Quality Improvement and Systems Thinking}

I have incorporated Essential II by using scientific findings from nursing and other sciences to evaluate Teach-back to improve safety of the patients by reducing falls and falls with injury. In planning for implementation of my project a budget was developed as well as a cost/benefit analysis. I have made use of advanced communication skills to obtain approval and buy-in for a project that is designed to reduce risk for the patient organization and improve health outcomes. 


\section{Clinical Scholarship and Analytical Methods for Evidence-Based Practice}

The heart of my project is rooted in Essential III. Every competency associated with Essential III has been achieved over the course of the past several months. Analytical methods were used to critically appraise existing literature as I sought to determine if Teach-back was a best-practice intervention. My project was designed based upon the evidence and clinical practice guidelines. I have collected outcomes data following implementation of Teach-back and have analyzed the data to evaluate those outcomes.

\section{Information Systems/Technology and Patient Care Technology for the Improvement and Transformation of Health Care}

I have been able to incorporate Essential IV by accessing and analyzing the falls and falls with injury data obtained from the Risk Management database. Additionally, I accessed electronic health records to evaluate patient teaching as well as obtaining and analyzing patient census lists for demographic data. My project also required that I evaluate consumer health information sources from multiple sources to establish that what we were teaching the patients was accurate, timely, and appropriate.

\section{Health Care Policy for Advocacy in Health Care}

The problem of patient falls in my institution far exceeds acceptable benchmarks. Numerous interventions have been tried with little success. This is what led me to the intervention of Teach-back. I have been working with the "Falls Team” in conjunction with my project and have recently been made the chair of the team as a result of my project. I believe that this will allow me to influence leaders from different disciplines such as physical therapy to expand the use of Teach-back when educating patients especially about falls prevention. 


\section{Interprofessional Collaboration for Improving Patient and Population Health}

The development of this project required both intraprofessional and interprofessional collaboration allowing me to incorporate the principles of Essential VI. Intraprofessionally, meetings had to be held with the nurse manager, nurse coordinator and nurse director of the department where the project was going to take place. I met with all of the registered nurses on the department to gain their buy in and cooperation. Interprofessionally, I worked with Risk Management to obtain the falls data I needed and to consult with them on trends they were seeing with falls. I also worked with the Organizational Development and Learning Department as they are responsible for all education in the hospital. In all cases, I found everyone easy to work with and felt my project was reflective of this cooperation. Moving forward, I will be leading an interprofessional team to expand the use of Teach-back by other disciplines.

\section{Clinical Prevention and Population Health for Improving the Nation's Health}

The expanding problem of falls among older adults has risen to alarming levels in the United States and is projected to continue to grow, increasing costs that cannot be sustained economically. As such, I have researched epidemiological, biostatistical, environmental, and cultural dimensions as described in Essential VII in an effort to fully understand falls in older adults. This research led me to evaluation of various interventions designed to prevent falls and improve care for individuals and groups of individuals. Teach-back is a strategy that can be used in diverse communities, socioeconomic classes and cultures to help address this national problem that threatens population health. 


\section{Advanced Nursing Practice}

My project has provided me with the opportunity to practice the essential of Advanced Nursing Practice by educating, guiding and supporting other nurses to develop therapeutic partnerships with patients. Such partnerships are formed when the nurse uses the evidence-based intervention of Teach-back as their method of educating patients. Teach-back encourages patients to become active participants in their own care and then assume accountability for safe practices such as activities associated with falls prevention during a hospitalization experience.

\section{Conclusion:}

Falls involving older adult patients are largely preventable events that can result in injury, loss of independence, devastating economic consequences and even death. The problem of inpatient falls has been documented for over 50 years (Currie, 2008). Historically falls prevention programs that have utilized generalized falls precautions and/or relied solely on expensive pieces of equipment to address inpatient falls have been ineffective. A focused strategy to reduce falls in older adults is to involve them in their own care by effectively communicating why they are at risk and what they themselves can do to prevent a fall. Teachback is a simple and low-cost, evidence-based intervention that can improve the safety and quality of care for the older adult patient in the inpatient setting. 


\section{References}

Agency for Healthcare Research and Quality. (2013). Preventing falls in hospitals: How

do you measure fall rates and fall prevention practices? Retrieved from:

http://www.ahrq.gov/professionals/systems/hospital/fallpxtoolkit/fallpxt5.html

Agency for Healthcare Research and Quality. (2014). Fall prevention toolkit facilitates

customized risk assessment and prevention strategies, reducing inpatient falls.

Retrieved from: http://www.innovations.ahrq.gov/content.aspx?id=3094.

Alspach, G. (2006). Nurses’ use and understanding of evidence-based practice: Some

preliminary evidence. Critical Care Nurse, 26(6), 11-12. Retrieved from:

http://ccn.aacnjournals.org/content/26/6/11.full

Always Use Teach-back! (2015). Retrieved from: http://www.teachbacktraining.org

Amplion Clinical Communications. (n.d.) An assessment of falls in patients' rooms andAl/

wp-content/uploads/white-paper-falls-assessment.pdf

Anderson, J.L., Dodman, S., Kopelman, M. \& Fleming, A. (1979). Patient information

recall in a rheumatology clinic. Rheumatology, (18)1, 18-22. doi: 10.1093/

rheumatology/18.1.18 
Aschkenasy, M.T., \& Rothenhaus, T.C. (2006). Trauma and falls in the elderly. Emergency Medicine Clinics of North America, 24(2), 413-432. Retrieved from: http://geriem.com/wp-content/uploads/2013/04/Trauma-and-Falls-in-the-Elderly-from EmergMedClin_413.pdf

Basiphobia (n.d.). In The American Heritage Stedman's Medical Dictionary. Retrieved September 22, 2015, from Dictionary.com from http://dictionary.reference.com/browse/ basiphobia

Bates, O.L., O’Conner, N., Dunn, D., \& Hasenau, S.M. (2014). Applying STAAR interventions in incremental bundles: Improving post-CABG surgical patient care. Worldviews on Evidence-Based Nursing, 11(2), 89-97. doi: 10.1111/wvn.12028

Bloch, F., Thibaud, M., Duque, B., Breque, C., Rigaud, A.S. \& Kemoun, G. (2010). Episodes of falling among elderly people: a systematic review and meta-analysis of social and demographic predisposing characteristics. Clinics (65), 985-903. doi: 10.1590/S180759322010000900013

Bouschon, B., Neilson, G., Quigley, P., Rutherford, P., Taylor J., Shannon, D. \& Rita, S. (2012). How to guide: Reducing patient injuries from falls. Retrieved from: http:/www.ihi.org/ resources/Pages/Tools/TCABHowToGuideReducingPatientInjuriesfromFalls.aspx 
Bowen, R.L. \& Atwood, C.S. (2004). Living and dying for sex. A theory of aging based on the modulation of cell cycle signaling by reproductive hormones. Gerontology, 50(5), 265-90 doi: 10.1159/000079125

Caldwell, E. (2014). What nurses need to know and do to offer evidence-based care. The Ohio State Research and Innovation Communications. Retrieved from: http://researchnews.osu. /archive/Ebpcomp.htm

Centers for Disease Control and Prevention. (2015) Falls among older adults: An overview. Retrieved from: http://www.cdc.gov/homeandrecreationalsafety/falls/adultsfalls.html

Centers for Disease Control and Prevention. (2006). Preventing chronic disease: Public health research practice and policy. Retrieved from: http://www.cdc.gov/pcd/issues/2006/ oct/06_0067.htm

Centers for Medicare and Medicaid (2009) Medicare program; Changes to the hospital inpatient prospective payment systems and fiscal year 2009 rates [final rule]. Retrieved from http://www.cms.gov/Medicare/Medicare-Fee-for-Service-Payment/AcuteInpatientPPS/ IPPSRegulations-and-Notices-Items/CMS1227598.html

Cignole, C.T., Langa, K.M., Kabeto, M.U., Tian, Z. \& Blaum, C.S. (2007). Geriatric conditions and disability: The health and retirement study. Annals of Internal Medicine, (147)156-164. doi:10.7326/0003-4819-147-3-200708070-00004 
Coyne, C.A., Demian-Popescu, C. \& Friend, D. (2006). Social and cultural factors influencing health in southern West Virginia: A qualitative study. Preventing Chronic Disease; Public Health Research, Practice, and Policy,3(4): A124. Retrieved from: http://www.ncbi.nlm. nih.gov/pmc/articles/PMC1779288/

Currie, L. (2008). Fall and injury prevention. In R.G. Hughes (Ed.), Patient safety and quality: An evidence-based handbook for nurses (pp. 195-250). Rockville MD: Retrieved from: http://archive.ahrq.gov/professionals/cliniciansproviders/resources/nursing/resources /nurseshdbk/CurrieL_FIP.pdf

Dantic, D.E. (2014). A critical review of the effectiveness of “Teach-back” technique in teaching COPD patients self-management using respiratory inhalers. Health Education Journal, 73(1),41-50. doi:10.1177/0017896912469575

Degelau, J., Belz, M., Bungum, L., Flavin, P.L., Harper, C., Leys, K.,...Webb, B. (2012) Institute for clinical systems improvement health care protocol: Prevention of falls (acute Care). Retrieved from: https://www.icsi.org/_asset/dcn15z/Falls-Interactive0412.pdf Denham, S.A., Meyer, M.G. Toborg, M.A. \& Mande, M.J. (2004). Providing health education to Appalachia populations. Holistic Nursing Practice, 8(6), 293-301.doi: 10.1097/00004650200411000-00005 
Dinh, T.T. H, Clark R., Bonner, A. \& Hines, S. (2013). The effectiveness of health education using the teach-back method on adherence and self-management in chronic disease: a systematic review protocol. JBI Database of Systematic Reviews and Implementation Reports, 11(10), 30-41. doi: 10.11124/jbisrir-2013-900.

Dinneen, L.C. \& Blakesley, B.C. (1973). Algorithm AS 62: A generator for the sampling Distribution of the Mann-Whitney U statistic. Journal of the Royal Statistical Society Series C, 22(2), 269-273. doi:10.2307/2346934

Edgman-Levitan, S. (2004). Involving the patient in safety efforts. In Leonard, M., Frankel, A., \& Simmonds, T. (Eds.), Achieving safe reliable healthcare (pp. 81-93). Chicago Retrieved from: https://www.ache.org/pdf/secure/gifts/july10-leonard.pdf ERCI Institute (2009) Healthcare risk control. Retrieved from https://www.ecri.org/ Documents/RM/HRC_TOC/SafSec2.pdf

Fortin, M., Bravo, G., Hudon, C., Vanasse, A. \& Lapointe, L. (2005). Prevalence of multimorbidity among adults seen in family practice. The Annals of Family Medicine (3) 3, 223-228. Retrieved from: http://www.annfammed.org/content/3/3/223.full.pdf Fuhrmans, V. (2008, January 15). Insurers stop paying for care linked to errors. Health plans say new rules improve safety and cut costs; Hospitals can’t dun patients. The Wall Street Journal. Retrieved from: http://www.wsj.com/articles/SB120035439914089727 
Griffey, R.T., Shin, N., Jones, S., Aginam, N., Gross, M., Kinsella, Y.,...Kaphingst, K.A. (2015) The impact of Teach-back on comprehension of discharge instructions and satisfaction among emergency patients with limited health literacy: a randomized, controlled study. Journal of Communication in Healthcare, 8(1), 10-21. doi:

10.1179/1753807615Y 0000000001

Gross, M.E., Kinsella, Y., Griffey, R., Shin, N., Aginam, N., Jones, S....Kaphingst. K. (2013). Limitations of teach-back method in the emergency department. Academic Emergency Medicine, 20(1). doi: 10.1111/acem.12115

Haines, T., Hill, A.M., Hill, K., Brauer, S., Hoffmann, T., Etherton-Beer, C., McPhail, S.

(2013). Cost effectiveness of patient education for the prevention of falls in hospital:

Economic evaluation from a randomized controlled trial. BMC Medicine, 11(135) doi:

10.1186/1741-7015-11-135

Healthy People 2020 (2015) Retrieved from: http://www.healthypeople.gov/

Hitcho, E.B., Krauss, M.J., Birge, S., Dunagan, W.C., Fischer, I., Johnson, S., Nast, P.A., Costantinou, E., \& Fraser, V.J. (2004). Characteristics and circumstances of falls in a hospital setting: A prospective analysis. Journal of General Internal Medicine, 19, 732739. doi: 10.1111/j.1525-1497.2004.30387.x 
Howie-Esquivel, J., White, M., Carroll, M.,\& Brinker, E. (2011). Teach-back is an effective strategy for educating older heart failure patients. Journal of Cardiac Failure, 17(8) doi: http://dx.doi.org/10.1016/jcardiacfail2011.06.345

Howie-Esquivel, J., Bibbons-Domingo, K., Clark, R., Evangelista, L., \& Dracup, K. (2014). A culturally appropriate educational intervention can improve self-care in Hispanic Patients with heart failure: A pilot randomized controlled trial. Cardiology Research, 5(3-4), 91-100. doi: http://dx.doi.org/10.14740/cr346w

Hsu, S., Wang, S., Shyu, S., Tseng, H., Lei, Y., \& Lee, Y. (2004). Fall risk factors assessment tool: enhancing effectiveness in falls screening. Journal of Nursing Research, 12(3), 169-178.

Hughes, K., Beurden, E. V., Eakin, E. G., Barnett, L. M., Patterson, L. M., Backhouse, J.,... Newman, B. (2008). Older persons perception of risk of falling: Implications for fallprevention campaigns. American Journal of Public Health, 98(2), 351-357. doi: 10.2105/AJPH.2007.115055

Huttlinger, K.W. \& Purnell. L.D. (2008). People of Appalachian heritage. In Transcultural Healthcare: A culturally competent approach. (3rd ed.). (pp. 95-112). Philadelphia: F.A. Davis. 
Hyrkas, K., \& Wiggins, M. (2014). A comparison of usual care, a patient-centered education intervention and motivational interviewing to improve medication adherence and readmissions of adults in an acute-care setting. Journal of Nursing Management, 22(3), doi: 10.1111/jonm.12221

Inouye, S.K., Studenski, S., Tinetti, M.E., \& Kuchel, G.A. (2007). Geriatric syndromes: Clinical, research, and policy implications of a core geriatric concept. Journal of the American Geriatrics Society, 55(5), 1-13. Retrieved from: http://www.ncbi.nlm.nih.gov/pmc /articles/PMC2409147/

Institute for Healthcare Improvement (2015). “Always Use Teach-back!”. Retrieved from: http://www.ihi.org/resources/Pages/Tools/AlwaysUseTeachBack!.aspx

Kandula, N.R., Malli, T. \& Zei, C.P. (2011). Literacy and retention of information after a multimedia diabetes education program and Teach-back. Journal of Health Communication,16(3), 89-102. doi:10.1080/10810730.2011.604382

Kececi, A.K. \& Bulduk, S. (2012). Health education for the elderly. Retrieved from: http:// www.intechopen.com/books/geriatrics/health-education-for-elderly-people Kessels, R. P. (2003) Patients' memory for medical information. Journal of the Royal Society of Medicine, 96(5), 219-222. Retrieved from: http://www.ncbi.nlm.gov/pmc/articles/ PMC 539473/ 
Kiel, D.P. (2014). Falls in older persons: Risk factors and patient evaluation. Up to Date.

Retrieved from: http://www.uptodate.com/contents/falls-in-older-persons-risk-factorsand-patient-evaluation\#H6

Konstantinos, S., Cheng, J.D., Gestring, M.L., Sangosanya, A., Stassen, N.A. \& Bankey, P.E. (2010). Ground level falls are associated with significant mortality in elderly patients. The Journal of Trauma: Injury, Infection and Critical Care, 69(4),821. doi:10/1097/TA.0b0133181efc6c6

Kourkouta, L. \& Papathanasiou, J.V. (2014). Communication in nursing practice. Journal of Medical Sciences of Bosnia and Hezegovina, 26(1), 65-67. doi: 10.5455/msm.2014.26.6567.

Kripalani, S., Bengtzen, R., Henderson, L.E. \& Jacobson, T.A. (2008). Clinical research in lowliteracy populations: Using Teach-back to assess comprehension of informed consent and privacy information. IRB: Ethics \& Human Research, 30(2), 13-19. Retrieved from: http://www.biomedsearch.com/article/Clinical-research-in-low-literacy/187427080.html 
LaBresh, K.A., Jarrett, N., \& Lux, L. (2011) Evidence-based guidelines for selected and previously considered hospital-acquired conditions. Report update (CMS contract No. 500-T00007): RTI International. Retrieved from http://www.cms.gov/Research-StatisticsData-and-Systems/Statistics-Trends-and-Reports/Reports/downloads/LaBresh_ and-Systems/Statistics-Trends-and-Reports/Reports/downloads/LaBresh_GuidelinesforHAC_June_2011.pdf

Larrabee, J.H. (2009). Nurse to nurse: Evidence based practice expert interventions. New York: McGraw-Hill.

Longtin, Y., Sax, H., Leape, L.L., Sheridan, S.E., Donaldson, L, \& Pittet, D. (2010). Patient participation: Current knowledge and applicability to patient safety. Mayo Clinic Proceedings, 85(1), 53-62.doi: 10.4065/mcp.2009.0248

Martin, J.E., \& Sheaff, M.T. (2007). The pathology of ageing: Concepts and mechanisms. Journal of Pathology, 211(2), 111-113. doi: 10.1002/path.2122

McCambridge, J., Witton, J. \& Elbourne, D.R. (2014). Systematic review of the Hawthorne effect: New concepts are needed to study research participation effects. Journal of Clinical Epidemiology, 67(3) 267-277. doi:http:dx.doi.org/10.1016/j.jclinepi.2013.08.015 
Melnyk, B. M. \& Fineout-Overholt, E. (2011). Evidence-based practice in nursing \& healthcare: A guide to best practice (2nd ed.). Philadelphia. Wolters Kluwer Health/Lippincott William \& Wilkins.

Melzer, I., Benjuya, J., \& Kaplanski, J. (2004). Postural stability in the elderly: A comparison between fallers and non-fallers. Age and Ageing, 33(6) 602-607. doi: 10.1093/ ageing/afh218

Michael, Y.L., Lin, J.S., Whitlock, E.P., Gold, R., Fu, R., O’Conner, E.A.,...Lutz, K.W. (2010). Interventions to prevent falls in older adults: An updated systematic review (AHRQ Publication No. 11-05150-EF-1). Retrieved from: file://C:/Users/elizabeth/Downloads/ fallspreves.pdf

Miller, K.S. (2010). Older adults' perception of fall-prevention education: A qualitative study. (Unpublished master’s thesis). Western Carolina University, Cullowhee, N.C. Retrieved from: http://libres.uncg.edu/ir/wcu/f/Miller2010.pdf

Muir, S.W., Berg, K., Chesworth, B.M., Klar, N., \& Speechley, M. (2010). Modifiable risk factors identify people who transition from non-fallers to fallers in community-dwelling older adults: A prospective study. Physiotherapy Canada, 62(4), 358-367. doi: $10.3138 /$ physio.62.4.358 
National Database of Nursing Quality Indicators. (2014). Guidelines for data collection on the American Nurses Association’s National Quality Forum endorsed measures.

Kansas City, KS: University of Kansas Medical Center. Retrieved from:

http://www.nursing quality.org/Content/Documents/NQF-Data-Collection-Guidelines.pdf

National Quality Forum. (2010). Safety practice for better healthcare-2010 update: A

Consensus report. Retrieved from: file://C./Users/elizabeth/Downloads/Safe\%20

Practuces\%2010\%20Full\%20(1).pdf

Negarandeh, R., Mahmoodi, H., Noktehdan, H., Heshmat, R. \& Shakibazadeh, E. (2013).

Teachback and pictorial image educational strategies on knowledge about

diabetes and medication/dietary adherence among low health literate patients with type 2

diabetes. Primary Care Diabetes, 7(2), 111-118. doi: 10.1016/j.pcd.2012.11.001.

Nevins, A. (n.d.) Teaching older adults. Retrieved from: http://www.evidence2practice.org/

topics/Hartford

Nursing Theory. (2013). Retrieved from: http://www.nursing-theory.org/nursing-

theorists/Dorothea-E-Orem.php

Oliver, D., Healey, F., \& Haines, T. (2010). Preventing falls and fall-related injuries in hospitals.

Clinical Geriatric Medicine, 26, 645-692

Orem, D.E. (1995). Nursing: Concepts of Practice (5th ed.). St. Louis: Mosby 
Orem, D.E. (1997). Views of human beings specific to nursing. Nursing Science Quarterly, 10(1), 126-131.doi: 10.1177/089431849701000110

Picker Institute. (2012). Always Events Blueprint for Action: Improve Patient Experience, Engage Staff, Transform Healthcare. Retrieved from: http://alwaysevents. pickerinstitute.org/?p=1759

Pollard, K., \& Jacobsen, L.A. (2015) The Appalachian region: A data overview from the 20092013 American community survey. Retrieved from: http://www.arc.gov/ research/researchreportdetails.asp?REPORT_ID=114

Quigley, P.A., Hahm, B., Gibson, W., Powell-Cope, G., Sarduy, I., Tyndall, K., \& White, S. (2009). Reducing serious injury from falls in two Veterans’ hospital medical-surgical units. Journal of Nursing Care Quality, 24(1), 33-41. doi: 10.1097/NCQ.0b013e31818f528e

Radey, L.A., \& LaBresh, K.A. (2012). Evidence-based guidelines for selected and previously considered hospital-acquired conditions. Centers for Medicare and Medicaid Innovation. (RTI Project Number 0209853.231.002.122). Retrieved from www.cms.gov/Medicare/ Medicare-Fee-for-Service-Payment/HospitalAcqCond/Downloads/Evidence-BasedGuidelines.pdf 
Reinhart, A. (2015). When differences in significance aren’t significant differences In: Statistics

Done Wrong. Retrieved from: http://www.statisticsdonewrong.com/significantdifferences.html

Rubenstein, L.Z. (2006). Falls in older people: Epidemiology, risk factors and strategies for prevention. Age and Ageing, 35(2), ii37-ii41. doi: 10.1093/ageing/afl084

Rudd, R.E. (2009). Overview: Low health literacy among older adults. In Improving Health Literacy for Older Adults: Expert Panel Report (pp.5-6). U.S. Department of Health and Human Services: Centers for Disease Control and Prevention. Retrieved from: http://www.cdc.gov/healthliteracy/pdf/olderadults.pdf

Schiller, J.S., Kramarow, E.A. \& Dey, A.N. (2007). Fall injury episodes among noninstitutionalized older adults: United States, 2001-2003. Advance Data 392(392), 1-6.

Schillinger, D., Piette, J., Grumback, K., Wang, F., Wilson, C., Daher, C....Bindman, A.B. (2003). Closing the loop: Physician communication with diabetic patients who have low health literacy. Archives of Internal Medicine 163(1), 83-90. doi:

10.1001/archinte.163.1.83

Scottish Intercollegiate Guidelines Network. (2015). Critical appraisal: Notes and checklist. Retrieved from http://www.sign.ac.uk/methodology/checklist.html 
Soriano, T.A., DeCherrie, L.V., \& Thomas, D.C. (2007). Falls in the community-dwelling older Adult: A review for primary-care providers. Clinical Interventions Aging, 2(4), 545-553. Retrieved from: http://dx.doi.org/10.2147/CIA.S1080

Statistics how to (2015). Face Validity: Definition and Examples. Retrieved from: http://www.statisticshowto.com/face-validity/

Stevens, J.A., Corso, P.S., Finkelstein, E.A., \& Miller, T.R. (2006). The cost of fatal and non-fatal falls among older adults. Injury Prevention, 12(5), 290-295. doi: 10.1136/ ip.2005.011015

Sudore, R.L., \& Schillinger, D. (2009). Interventions to improve care for patients with limited Literacy. Journal of Clinical Outcomes Management, 16(1). 20-29. Retrieved from: http://www.ncbi.nlm.nih.gov/pmc/articles/PMC2799039/pdf/nihms88660.pdf

Sudore, R.L., Yaffe, K., Satterfield, S., Harris, T.B., Mehta, K.M., Simonsick, E.M.,... Schillinger, D. (2006). Limited literacy and mortality in the elderly: The health, aging, and body composition study. Journal of General Internal Medicine, 21, 806-812.

doi: 10.1111/j.1525-1497.2006.00539.x

Tabloski, P.A. (2010). Challenges of aging and cornerstones of excellence in nursing care (2nd ed). In: P.A. Tabloski (Ed.), Gerontological Nursing (pp. 87-343). Upper Saddle River NJ: Prentice-Hall. 
The Joint Commission (2007). “What did the doctor say?”. Improving health literacy to protect Patient safety. Retrieved from: http://www.jointcommission.org/assets/1/18/improving_ health_literacy.pdf

The Joint Commission Online. (2014) Center for transforming healthcare. Retrieved from: http:// www.centerfortransforminghealthcare.org/assets/4/6/CTH_PFWI_Fact_Sheet.pdf

Theory Based Nursing Practice (2014). Unpublished manuscript, Department of Nursing, University of Tennessee at Chattanooga, Chattanooga, Tennessee. Retrieved from: http://www.utc.edu/nursing/pdfs/classes/orem-handbook.pdf

Todd, C., \& Skelton, D. (2004). What are the main risk factors for falls among older people and what are the most effective interventions to prevent these falls? Health Evidence Network Report. Retrieved from: http://www.euro.who.int/document/E82552.pdf

U.S. Census Bureau (2015). State and county quick facts. Retrieved from: http://quickfacts. census.gov/qfd/index.html

U.S. Department of Health and Human Services. (2011). A profile of older Americans: 2011. Retrieved from: http://www.aoa.gov/aoaroot/aging_statistics/Profile/2011/docs/ 2011profile.pdf

U.S. Department of Health and Human Services. (2015). Healthy people 2020. Retrieved from http://www.healthypeople.gov/2020/default.aspx 
U.S. Preventive Services Task Force (2012). Final recommendation statement: Fall prevention in older adults: Counseling and preventive medication. Retrieved from: http://www. uspreventiveservicestaskforce.org/Page/Document/RecommendationStatementFinal/ falls-prevention-in-older-adults-counseling-and-preventive-medication

Visschedijk, J., Achterberg, W., van Balen, R., \& Hertogh, C. (2010). Fear of falling after hip fracture: A systematic review of measurement instruments, prevalence, interventions and related factors. Journal of the American Geriatric Society, 58, 17391748. doi: 10.1111/j.1532-5415.2010.03036.x

White, M., Garbez, R., Carroll, M., Brinker, E. \& Howie-Esquivel, J. (2013). Is “Teach-back” associated with knowledge retention and hospital readmission in hospitalized heart failure patients? Journal of Cardiovascular Nursing, 28(2), 137-146. Retrieved from: http://nursingcenter.com/JournalArticle?Article_ID=1504599

Wilson, F.L. Baker, L.M., Nordstrom, C.K. \& Legwand, C. (2008). Using the Teach-back and Orem's self-care deficit nursing theory to increase childhood immunization Communication among low-income mothers. Issues in Comprehensive Pediatric Nursing, 31(1), 7-22. doi: 10.1080/01460860701877142. 
Wilson, F.L., Mayeta-Peart, A., Parada-Webster, L. \& Nordstrom, C. (2012). Using the teachback method to increase maternal immunization literacy among low-income pregnant women in Jamaica: A pilot study. Journal of Pediatric Nursing, 27(5), 451-459. doi: http://dx.doi.org/10.1016/j.pedn.2011.05.004

World Health Organization. (2007). WHO global report on falls prevention in older age. Retrieved from http://www.who.int/ageing/publications/Falls_prevention7March.pdf

World Health Organization. (2012). Falls: Fact sheet N³44. Retrieved from: http://www. who.int/mediacentre/factsheets/fs344/en/

Yardley, L., Donovan-Hall, M., Francis, K., \& Todd, C. (2006). Older people's views of advice about falls prevention: a qualitative study. Health Education Research, 21(4), 508-17. doi: 10.1093/her/cyh077 


\section{Teach-back Obsęrvation Tool}

Care Team Member:

Date:

Observer: Time:

\begin{tabular}{|c|c|c|c|c|}
\hline Did the care team member... & Yes & No & $\mathbf{N} / \mathbf{A}$ & Comments \\
\hline \multicolumn{5}{|c|}{ Use a caring tone of voice and attitude? } \\
\hline \multicolumn{5}{|l|}{$\begin{array}{l}\text { Display comfortable body language, } \\
\text { make eye contact, and sit down? }\end{array}$} \\
\hline \multicolumn{5}{|l|}{ Use plain language? } \\
\hline \multicolumn{5}{|c|}{$\begin{array}{l}\text { Ask the patient to explain in their own } \\
\text { words what they were told to do about: } \\
\text { - Signs and symptoms they should call } \\
\text { the doctor for? } \\
\text { - Key medicines? } \\
\text { - Critical self-care activities? } \\
\text { - Follow-up appointments? }\end{array}$} \\
\hline \multicolumn{5}{|l|}{$\begin{array}{l}\text { Use non-shaming, open-ended } \\
\text { questions? }\end{array}$} \\
\hline \multicolumn{5}{|l|}{$\begin{array}{l}\text { Avoid asking questions that can be } \\
\text { answered with a yes or no? }\end{array}$} \\
\hline \multicolumn{5}{|l|}{$\begin{array}{l}\text { Take responsibility for making sure } \\
\text { they were clear? }\end{array}$} \\
\hline \multicolumn{5}{|l|}{$\begin{array}{l}\text { Explain and check again if the patient } \\
\text { is unable to use teach-back? }\end{array}$} \\
\hline \multicolumn{5}{|l|}{$\begin{array}{l}\text { Use reader-friendly print materials to } \\
\text { support learning? }\end{array}$} \\
\hline \multicolumn{5}{|l|}{$\begin{array}{l}\text { Document use of and patient's } \\
\text { response to teach-back? }\end{array}$} \\
\hline $\begin{array}{l}\text { Include family members/caregivers } \\
\text { if they were present? }\end{array}$ & & & & \\
\hline
\end{tabular}


Appendix B

Fall Prevention Teach-Back Guide for Nurses

Who: Patients 65 and older

When: Complete within 1 hour of admission assessment

Where: At the bedside in the patient's room

What:

$\checkmark$ Top 3 Reasons why you are at higher risk for falling

- Age + (if applicable)

- Ambulation Assistive Devices

- IVs

- Drugs

- Previous History of Falls

- Weakness

- Shortness of Breath

- Woman

$\checkmark$ The 3 main reasons fall prevention is important

- Falls for the most part are preventable

- Falls can result in injury

- Falls can make your hospital stay longer 
$\checkmark$ The number one reason patients fall in the hospital

Patients trying to walk to and from the bathroom themselves

(Hitcho et al., 2004)

$\checkmark$ What you can do to prevent falling

- Call Don’t Fall!

Locate the call light in the bathroom and at the bedside and demonstrate how to use it!

- Wait for Help

- Wear non-slip footwear

\section{Test their knowledge}

"I want to be sure that I did a good job of teaching you about staying safe from falling while you are in the hospital. Can you please tell me in your own words how you can prevent falling”?

1. What are the top 3 reasons you are at risk for falling and/or injury?

- (Based on your fall risk assessment and history of injury risk)

2. What are the 3 main safety reasons fall prevention is important?

- Falls for the most part are preventable

- Falls can result in injury

- Falls can make your hospital stay longer

3. What can you do to prevent fall? 


\section{Call Don’t Fall!}

Locate the call light in the bathroom and at the bedside and demonstrate how to use it!

- Wait for Help

- Wear non-slip footwear

4. Find and demonstrate the use of the call light

Source: Boushon, B., Nielson, G., Quigley, P., Rutherford, P., Taylor, J., Shannon, D. \& Rita, S. (2012). How-to guide: Reducing patient injuries from falls. Retrieved from: http://www.ihi.org/resources/Pages/Tools/TCABHowToGuideReducingPatientInjuries fromFalls.aspx 


\section{Appendix C}

\section{Methodology Checklist 1: Systematic Reviews and Meta-analyses}

SIG N

Study identification (Include author, title, year of publication, journal title, pages)

Guideline topic:

Key Question No:

Checklist completed by:

\section{SECTION 1: INTERNAL VALIDITY}

\begin{tabular}{|c|c|c|c|}
\hline \multicolumn{2}{|c|}{ In a well conducted systematic review } & \multicolumn{2}{|c|}{ In this study this criterion is:: } \\
\hline 1.1 & $\begin{array}{l}\text { The study addresses an appropriate and clearly focused } \\
\text { question. }\end{array}$ & $\begin{array}{l}\text { Well covered } \\
\text { Adequately addressed } \\
\text { Poorly addressed }\end{array}$ & $\begin{array}{l}\text { Not addressed } \\
\text { Not reported } \\
\text { Not applicable }\end{array}$ \\
\hline 1.2 & A description of the methodology used is included. & $\begin{array}{l}\text { Well covered } \\
\text { Adequately addressed } \\
\text { Poorly addressed }\end{array}$ & $\begin{array}{l}\text { Not addressed } \\
\text { Not reported } \\
\text { Not applicable }\end{array}$ \\
\hline 1.3 & $\begin{array}{l}\text { The literature search is sufficiently rigorous to identify all } \\
\text { the relevant studies. }\end{array}$ & $\begin{array}{l}\text { Well covered } \\
\text { Adequately addressed } \\
\text { Poorly addressed }\end{array}$ & $\begin{array}{l}\text { Not addressed } \\
\text { Not reported } \\
\text { Not applicable }\end{array}$ \\
\hline 1.4 & Study quality is assessed and taken into account. & $\begin{array}{l}\text { Well covered } \\
\text { Adequately addressed } \\
\text { Poorly addressed }\end{array}$ & $\begin{array}{l}\text { Not addressed } \\
\text { Not reported } \\
\text { Not applicable }\end{array}$ \\
\hline 1.5 & $\begin{array}{l}\text { There are enough similarities between the studies } \\
\text { selected to make combining them reasonable. }\end{array}$ & $\begin{array}{l}\text { Well covered } \\
\text { Adequately addressed } \\
\text { Poorly addressed }\end{array}$ & $\begin{array}{l}\text { Not addressed } \\
\text { Not reported } \\
\text { Not applicable }\end{array}$ \\
\hline \multicolumn{4}{|c|}{ SECTION 2: OVERALL ASSESSMENT OF THE STUDY } \\
\hline 2.1 & $\begin{array}{l}\text { How well was the study done to minimise bias? } \\
\text { Code }++,+, \text { or }-\end{array}$ & & \\
\hline 2.2 & $\begin{array}{l}\text { If coded as }+ \text {, or }- \text { what is the likely direction in which } \\
\text { bias might affect the studv results? }\end{array}$ & & \\
\hline
\end{tabular}




\begin{tabular}{|c|c|c|c|c|}
\hline 3.1 & $\begin{array}{l}\text { What types of study are included in the review? } \\
\text { (Highlight all that apply) }\end{array}$ & $\begin{array}{l}\text { RCT } \\
\text { Case-control }\end{array}$ & $\begin{array}{l}\text { CCT } \\
\text { Other }\end{array}$ & Cohort \\
\hline 3.2 & $\begin{array}{l}\text { How does this review help to answer your key question? } \\
\text { Summarise the main conclusions of the review and how } \\
\text { it relates to the relevant key question. Comment on any } \\
\text { particular strengths or weaknesses of the review as a } \\
\text { source of evidence for a guideline produced for the NHS } \\
\text { in Scotland. }\end{array}$ & & & \\
\hline
\end{tabular}




\begin{tabular}{|c|c|c|}
\hline & bias might affect the study results? & \\
\hline 2.3 & $\begin{array}{l}\text { Taking into account clinical considerations, your } \\
\text { evaluation of the methodology used, and the statistical } \\
\text { power of the study, are you certain that the overall effect } \\
\text { is due to the study intervention? }\end{array}$ & \\
\hline 2.4 & $\begin{array}{l}\text { Are the results of this study directly applicable to the } \\
\text { patient group targeted by this guideline? }\end{array}$ & \\
\hline \multicolumn{3}{|c|}{$\begin{array}{l}\text { SECTION 3: DESCRIPTION OF THE STUDY The following information is required to complete evidence } \\
\text { tables facilitating cross-study comparisons. Please complete all sections for which information is available } \\
\text { PLEASE PRINT CLEARLY }\end{array}$} \\
\hline
\end{tabular}

\begin{tabular}{|c|c|}
\hline 3.1 & $\begin{array}{l}\text { How many patients are included in this study? } \\
\text { Please indicate number in each arm of the study, at the } \\
\text { time the study began. }\end{array}$ \\
\hline 3.2 & $\begin{array}{l}\text { What are the main characteristics of the patient } \\
\text { population? } \\
\text { Include all relevant characteristics - e.g. age, sex, ethnic } \\
\text { origin, comorbidity, disease status, community/hospital } \\
\text { based }\end{array}$ \\
\hline 3.3 & $\begin{array}{l}\text { What intervention (treatment, procedure) is being } \\
\text { investigated in this study? } \\
\text { List all interventions covered by the study. }\end{array}$ \\
\hline 3.4 & $\begin{array}{l}\text { What comparisons are made in the study? } \\
\text { Are comparisons made between treatments, or between } \\
\text { treatment and placebo / no treatment? }\end{array}$ \\
\hline 3.5 & $\begin{array}{l}\text { How long are patients followed-up in the study? } \\
\text { Length of time patients are followed from beginning } \\
\text { participation in the study. Note specified end points } \\
\text { used to decide end of follow-up (e.g. death, complete } \\
\text { cure). Note if follow-up period is shorter than originally } \\
\text { planned. }\end{array}$ \\
\hline 3.6 & $\begin{array}{l}\text { What outcome measure(s) are used in the study? } \\
\text { List all outcomes that are used to assess effectiveness of } \\
\text { the interventions used. }\end{array}$ \\
\hline 3.7 & $\begin{array}{l}\text { What size of effect is identified in the study? } \\
\text { List all measures of effect in the units used in the study - } \\
\text { e.g. absolute or relative risk, NNT, etc. Include p values } \\
\text { and any confidence intervals that are provided. }\end{array}$ \\
\hline 3.8 & $\begin{array}{l}\text { How was this study funded? } \\
\text { List all sources of funding quoted in the article, whether } \\
\text { Government, voluntary sector, or industry. }\end{array}$ \\
\hline 3.9 & $\begin{array}{l}\text { Does this study help to answer your key question? } \\
\text { Summarise the main conclusions of the study and } \\
\text { indicate how it relates to the key question. }\end{array}$ \\
\hline
\end{tabular}




\section{Methodology Checklist 3: Cohort studies}

SIG N

Study identification (Include author, title, year of publication, journal title, pages)

Guideline topic:

Key Question No:

Checklist completed by:

\section{SECTION 1: INTERNAL VALIDITY}

\section{In a well conducted cohort study:}

1.1 The study addresses an appropriate and clearly focused question.
In this study the criterion is:

Well covered Not addressed

Adequately addressed Not reported

Poorly addressed Not applicable

\begin{tabular}{|c|c|c|c|}
\hline \multicolumn{4}{|c|}{ SELECTION OF SUBJECTS } \\
\hline 1.2 & $\begin{array}{l}\text { The two groups being studied are selected from source } \\
\text { populations that are comparable in all respects other } \\
\text { than the factor under investigation. }\end{array}$ & $\begin{array}{l}\text { Well covered } \\
\text { Adequately addressed } \\
\text { Poorly addressed }\end{array}$ & $\begin{array}{l}\text { Not addressed } \\
\text { Not reported } \\
\text { Not applicable }\end{array}$ \\
\hline 1.3 & $\begin{array}{l}\text { The study indicates how many of the people asked to } \\
\text { take part did so, in each of the groups being studied. }\end{array}$ & $\begin{array}{l}\text { Well covered } \\
\text { Adequately addressed } \\
\text { Poorly addressed }\end{array}$ & $\begin{array}{l}\text { Not addressed } \\
\text { Not reported } \\
\text { Not applicable }\end{array}$ \\
\hline 1.4 & $\begin{array}{l}\text { The likelihood that some eligible subjects might have } \\
\text { the outcome at the time of enrolment is assessed and } \\
\text { taken into account in the analysis. }\end{array}$ & $\begin{array}{l}\text { Well covered } \\
\text { Adequately addressed } \\
\text { Poorly addressed }\end{array}$ & $\begin{array}{l}\text { Not addressed } \\
\text { Not reported } \\
\text { Not applicable }\end{array}$ \\
\hline 1.5 & $\begin{array}{l}\text { What percentage of individuals or clusters recruited } \\
\text { into each arm of the study dropped out before the } \\
\text { study was completed. }\end{array}$ & & \\
\hline 1.6 & $\begin{array}{l}\text { Comparison is made between full participants and } \\
\text { those lost to follow up, by exposure status. }\end{array}$ & $\begin{array}{l}\text { Well covered } \\
\text { Adequately addressed } \\
\text { Poorly addressed }\end{array}$ & $\begin{array}{l}\text { Not addressed } \\
\text { Not reported } \\
\text { Not applicable }\end{array}$ \\
\hline \multicolumn{4}{|c|}{ ASSESSMENT } \\
\hline 1.7 & The outcomes are clearly defined. & $\begin{array}{l}\text { Well covered } \\
\text { Adequately addressed } \\
\text { Poorly addressed }\end{array}$ & $\begin{array}{l}\text { Not addressed } \\
\text { Not reported } \\
\text { Not applicable }\end{array}$ \\
\hline 1.8 & $\begin{array}{l}\text { The assessment of outcome is made blind to exposure } \\
\text { status. }\end{array}$ & $\begin{array}{l}\text { Well covered } \\
\text { Adequately addressed } \\
\text { Poorly addressed }\end{array}$ & $\begin{array}{l}\text { Not addressed } \\
\text { Not reported } \\
\text { Not applicable }\end{array}$ \\
\hline 1.9 & $\begin{array}{l}\text { Where blinding was not possible, there is some } \\
\text { recognition that knowledge of exposure status could } \\
\text { have influenced the assessment of outcome. }\end{array}$ & $\begin{array}{l}\text { Well covered } \\
\text { Adequately addressed } \\
\text { Poorly addressed }\end{array}$ & $\begin{array}{l}\text { Not addressed } \\
\text { Not reported } \\
\text { Not applicable }\end{array}$ \\
\hline 1.10 & The measure of assessment of exposure is reliable. & $\begin{array}{l}\text { Well covered } \\
\text { Adequately addressed } \\
\text { Poorly addressed }\end{array}$ & $\begin{array}{l}\text { Not addressed } \\
\text { Not reported } \\
\text { Not applicable }\end{array}$ \\
\hline
\end{tabular}




\begin{tabular}{|c|c|c|c|}
\hline 1.11 & $\begin{array}{l}\text { Evidence from other sources is used to demonstrate } \\
\text { that the method of outcome assessment is valid and } \\
\text { reliable. }\end{array}$ & $\begin{array}{l}\text { Well covered } \\
\text { Adequately addressed } \\
\text { Poorly addressed }\end{array}$ & $\begin{array}{l}\text { Not addressed } \\
\text { Not reported } \\
\text { Not applicable }\end{array}$ \\
\hline 1.12 & $\begin{array}{l}\text { Exposure level or prognostic factor is assessed more } \\
\text { than once. }\end{array}$ & $\begin{array}{l}\text { Well covered } \\
\text { Adequately addressed } \\
\text { Poorly addressed }\end{array}$ & $\begin{array}{l}\text { Not addressed } \\
\text { Not reported } \\
\text { Not applicable }\end{array}$ \\
\hline \multicolumn{4}{|c|}{ CONFOUNDING } \\
\hline 1.13 & $\begin{array}{l}\text { The main potential confounders are identified and } \\
\text { taken into account in the design and analysis. }\end{array}$ & $\begin{array}{l}\text { Well covered } \\
\text { Adequately addressed } \\
\text { Poorly addressed }\end{array}$ & $\begin{array}{l}\text { Not addressed } \\
\text { Not reported } \\
\text { Not applicable }\end{array}$ \\
\hline \multicolumn{4}{|c|}{ STATISTICAL ANALYSIS } \\
\hline 1.14 & Have confidence intervals been provided? & & \\
\hline \multicolumn{4}{|c|}{ SECTION 2: OVERALL ASSESSMENT OF THE STUDY } \\
\hline 2.1 & $\begin{array}{l}\text { How well was the study done to minimise the risk of } \\
\text { bias or confounding, and to establish a causal } \\
\text { relationship between exposure and effect? } \\
\text { Code }++,+, \text { or }-\end{array}$ & & \\
\hline 2.2 & $\begin{array}{l}\text { Taking into account clinical considerations, your } \\
\text { evaluation of the methodology used, and the statistical } \\
\text { power of the study, are you certain that the overall } \\
\text { effect is due to the exposure being investigated? }\end{array}$ & & \\
\hline 2.3 & $\begin{array}{l}\text { Are the results of this study directly applicable to the } \\
\text { patient group targeted in this guideline? }\end{array}$ & & \\
\hline \multicolumn{4}{|c|}{$\begin{array}{l}\text { SECTION 3: DESCRIPTION OF THE STUDY (Note: The following information is required for evidence tables to facilita } \\
\text { cross-study comparisons. Please complete all sections for which information is available). } \\
\text { PLEASE PRINT CLEARLY }\end{array}$} \\
\hline 3.1 & $\begin{array}{l}\text { How many patients are included in this study? } \\
\text { List the number in each group separately }\end{array}$ & & \\
\hline 3.2 & $\begin{array}{l}\text { What are the main characteristics of the study } \\
\text { population? } \\
\text { Include all relevant characteristics - e.g. age, sex, ethnic } \\
\text { origin, comorbidity, disease status, community/hospital } \\
\text { based }\end{array}$ & & \\
\hline 3.3 & $\begin{array}{l}\text { What environmental or prognostic factor is being } \\
\text { investigated in this study? }\end{array}$ & & \\
\hline 3.4 & $\begin{array}{l}\text { What comparisons are made in the study? } \\
\text { Are comparisons made between presence or absence of } \\
\text { an environmental / prognostic factor, or different levels } \\
\text { of the factor?? }\end{array}$ & & \\
\hline 3.5 & For how long are patients followed-up in the study?. & & \\
\hline 3.6 & $\begin{array}{l}\text { What outcome measure(s) are used in the study? } \\
\text { List all outcomes that are used to assess the impact of } \\
\text { the chosen environmental or prognostic factor. }\end{array}$ & & \\
\hline
\end{tabular}




\begin{tabular}{|l|l|l}
\hline 3.7 & $\begin{array}{l}\text { What size of effect is identified in the study? } \\
\text { List all measures of effect in the units used in the study - } \\
\text { e.g. absolute or relative risk. Include } p \text { values and any } \\
\text { confidence intervals that are provided. Note: Be sure to } \\
\text { include any adjustments made for confounding factors, } \\
\text { differences in prevalence, etc. }\end{array}$ & $\begin{array}{l}\text { How was this study funded? } \\
\text { List all sources of funding quoted in the article, whether } \\
\text { Government, voluntary sector, or industry. }\end{array}$ \\
\hline 3.9 & $\begin{array}{l}\text { Does this study help to answer your key } \\
\text { question? } \\
\text { Summarise the main conclusions of the study and } \\
\text { indicate how it relates to the key question.? }\end{array}$
\end{tabular}




\section{Appendix D}

\section{Larrabee Form for Quantitative Appraisal}

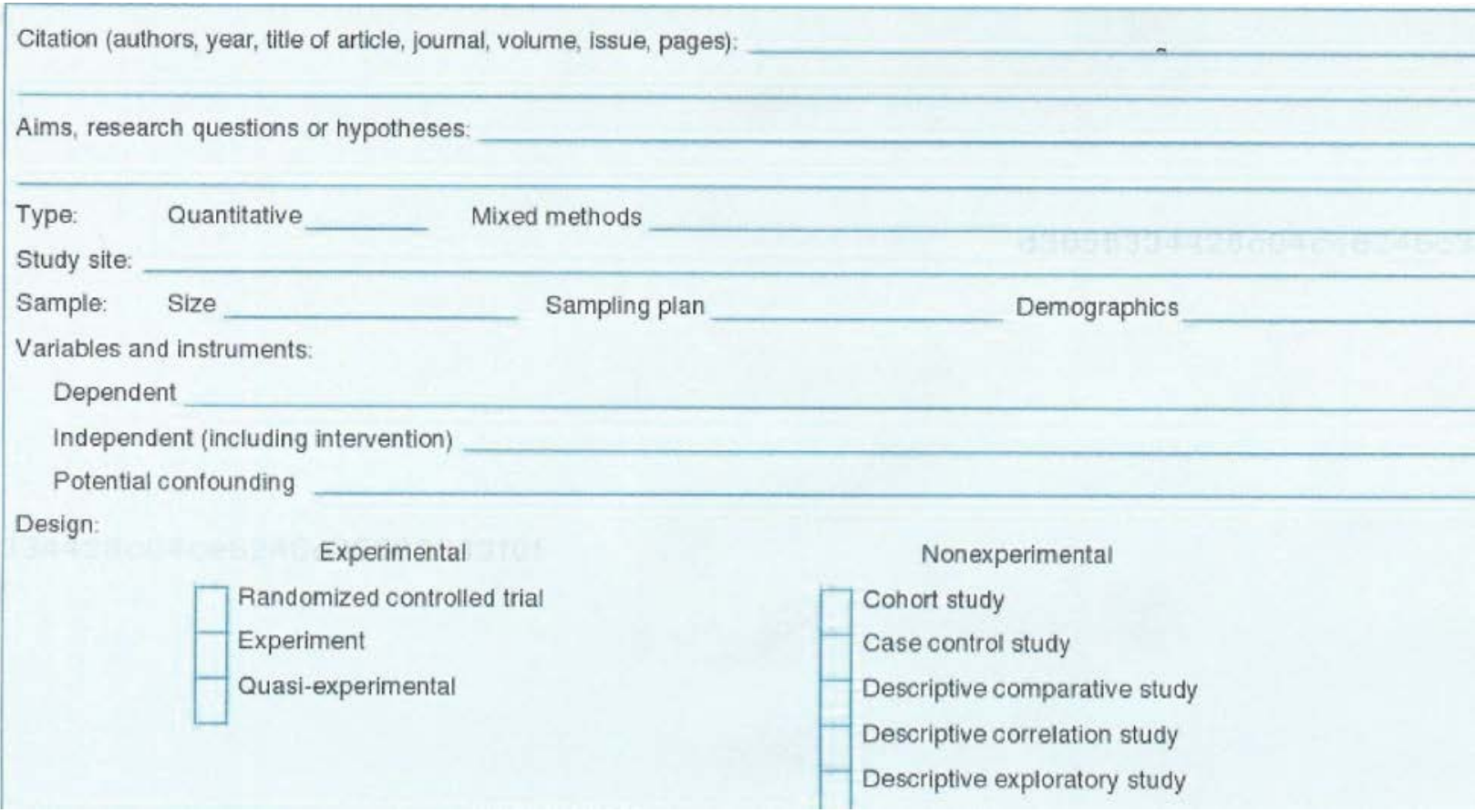

\footnotetext{
Results:

Recommendations:

Strengths:

Internal validity

External validity

Limitations:

Internal validity

External validity

Analysis

Clinical significance:

Credibility of results:

Intervention applicable to my setting:

Acceptability of benefit vs. risk:

Acceptability of costs:
} 
Citation (authors, year, title of article, journal, volume, issue, pages):

Aims, research questions or hypotheses:

\begin{tabular}{|l|l|l|}
\hline Type: & Quantitative & Mixed methods \\
\hline
\end{tabular}

Study site:

Sample: Size: Sampling plan:

Demographics:

Variables and

Dependent:

instruments

Independent (including intervention):

Potential confounding:

\begin{tabular}{|l|l|l|}
\hline Design & $\begin{array}{l}\text { Experimental } \\
\begin{array}{l}\text { Randomized } \\
\text { controlled trial }\end{array}\end{array}$ & Cohort study \\
\hline Experiment & $\begin{array}{l}\text { Case control study } \\
\text { Quasi- }\end{array}$ & $\begin{array}{l}\text { Descriptive comparative } \\
\text { study }\end{array}$ \\
\hline & $\begin{array}{l}\text { Descriptive correlation } \\
\text { study }\end{array}$ \\
\cline { 2 - 4 } & $\begin{array}{l}\text { Descriptive, exploratory } \\
\text { study }\end{array}$ \\
\hline
\end{tabular}

\section{Results:}

Recommendations: 


\begin{tabular}{ll}
\hline Strengths: Internal validity: & External validity \\
\hline Limitations: Internal validity: & External validity \\
\hline ANALYSIS \\
\hline
\end{tabular}

Clinical significance:

Credibility of results:

Intervention applicable to my setting:

Acceptability of benefit vs. risk:

Acceptability of costs: 


\section{Appendix E}

\section{Levels of Evidence}

Level 1 - Systematic review \& meta-analysis of randomized controlled trials; clinical guidelines based on systematic reviews or meta-analyses

Level 2 - One or more randomized controlled trials

Level 3 - Controlled trial (no randomization)

Level 4 - Case-control or cohort study

Level 5 - Systematic review of descriptive \& qualitative studies

Level 6 - Single descriptive or qualitative study

Level 7 - Expert opinion

Source: Melnyk, B.M. \& Fineout-Overholt, E. (2011). Evidence-based practice in nursing and healthcare: A guide to best practice. Philadelphia: Lippincott, Williams \& Wilkins. 


\section{Appendix F}

\section{Literature Review Findings}

Table 2

Comprehension and Retention of Information

\begin{tabular}{|c|c|c|c|c|}
\hline $\begin{array}{l}\text { Author(s) } \\
\text { and Year }\end{array}$ & $\begin{array}{l}\text { Topic } \\
\text { /Focus/Purpose }\end{array}$ & $\begin{array}{l}\text { Study Design } \\
\text { and Sample } \\
\text { Size }\end{array}$ & $\begin{array}{l}\text { Measured } \\
\text { Outcomes }\end{array}$ & Findings \\
\hline $\begin{array}{l}\text { Griffey et } \\
\text { al. (2015) }\end{array}$ & $\begin{array}{l}\text { To determine the } \\
\text { impact of the } \\
\text { Teach-back patient } \\
\text { education } \\
\text { methodology on } \\
\text { comprehension, } \\
\text { perceived } \\
\text { comprehension (of } \\
\text { the patient) and } \\
\text { satisfaction } \\
\text { regarding patient } \\
\text { teaching among } \\
\text { Emergency } \\
\text { Department (ED) } \\
\text { patients. }\end{array}$ & $\begin{array}{l}\text { Randomized } \\
\text { control trial } \\
\text { Patients were } \\
\text { randomized: } \\
212 \text { to the } \\
\text { Teach-back } \\
\text { group and } 196 \\
\text { patients to the } \\
\text { standard } \\
\text { discharge } \\
\text { instruction } \\
\text { group. Patients } \\
\text { were lost due } \\
\text { to a variety of } \\
\text { reasons } \\
\text { associated } \\
\text { with discharge, } \\
\text { resulting in } \\
127 \text { patients } \\
\text { being analyzed } \\
\text { in each group. }\end{array}$ & $\begin{array}{l}\text { Following } \\
\text { teaching, } \\
\text { patients were } \\
\text { assessed for } \\
\text { comprehension } \\
\text { and perceived } \\
\text { comprehension } \\
\text { of the patient } \\
\text { regarding } \\
\text { instructions on } \\
\text { diagnosis, ED } \\
\text { care, post ED } \\
\text { care and return } \\
\text { instructions. } \\
\text { Patient } \\
\text { satisfaction } \\
\text { with the patient } \\
\text { teaching was } \\
\text { assessed as } \\
\text { well. }\end{array}$ & $\begin{array}{l}\text { Investigators found that } \\
\text { patients in the Teach- } \\
\text { back group had higher } \\
\text { comprehension of post- } \\
\text { ED medications, self- } \\
\text { care and follow-up. } \\
\text { There was no change in } \\
\text { patient satisfaction or } \\
\text { perceived } \\
\text { comprehension. } \\
\text { The investigators } \\
\text { supported the use of } \\
\text { Teach-back. }\end{array}$ \\
\hline $\begin{array}{l}\text { Gross et al. } \\
\text { (2013) }\end{array}$ & $\begin{array}{l}\text { To measure } \\
\text { comprehension } \\
\text { concerning } \\
\text { diagnosis, ED } \\
\text { course, } \\
\text { medications, and } \\
\text { follow-up and } \\
\text { return instructions } \\
\text { among ED } \\
\text { patients. }\end{array}$ & $\begin{array}{l}\text { Randomized } \\
\text { control trial } \\
\text { Patients were } \\
\text { randomized to } \\
\text { two groups: } \\
\text { usual care } \\
\text { versus Teach- } \\
\text { back patient } \\
\text { education } \\
\text { methodology. }\end{array}$ & $\begin{array}{l}\text { Comprehension } \\
\text { concerning } \\
\text { 1) diagnosis, 2) } \\
\text { ED course, 3) } \\
\text { medications 4) } \\
\text { follow-up } \\
\text { 5) return } \\
\text { instructions }\end{array}$ & $\begin{array}{l}\text { The findings of the } \\
\text { study were mixed. } \\
\text { Improvement was noted } \\
\text { in comprehension of } \\
\text { follow-up instructions } \\
\text { only with no differences } \\
\text { between groups in the } \\
\text { other four topics of } \\
\text { teaching. }\end{array}$ \\
\hline
\end{tabular}




\begin{tabular}{|c|c|c|c|c|}
\hline & & $\begin{array}{l}\text { 251 patients } \\
\text { including } 122 \\
\text { Teach-back } \\
\text { and } 129 \\
\text { control } \\
\text { patients }\end{array}$ & & \\
\hline $\begin{array}{l}\text { Howie- } \\
\text { Esquivel, } \\
\text { Bibbins- } \\
\text { Domingo, } \\
\text { Clark, } \\
\text { Evangelista } \\
\text { \& Dracup } \\
\text { (2014) }\end{array}$ & $\begin{array}{l}\text { To determine if a } \\
\text { culturally and } \\
\text { health-literacy- } \\
\text { appropriate self- } \\
\text { care educational } \\
\text { intervention } \\
\text { (Teach-back) } \\
\text { would improve } \\
\text { self-care behaviors } \\
\text { and heart failure } \\
\text { knowledge } \\
\text { compared to a } \\
\text { usual care group } \\
\text { among a Hispanic } \\
\text { population }\end{array}$ & $\begin{array}{l}\text { Randomized } \\
\text { control trial } \\
42 \text { patients } \\
\text { included ( } 22 \text { in } \\
\text { the Teach- } \\
\text { back group } \\
\text { and } 20 \text { in the } \\
\text { usual care } \\
\text { group) } \\
\text { *Patients in } \\
\text { the Teach- } \\
\text { back } \\
\text { experimental } \\
\text { group received } \\
\text { education } \\
\text { concerning } \\
\text { high salt } \\
\text { foods, when to } \\
\text { call the } \\
\text { physician, } \\
\text { when to report } \\
\text { weight gain } \\
\text { and the use of } \\
\text { diuretics } \\
\text { *Patients } \\
\text { received nurse } \\
\text { initiated phone } \\
\text { calls every } 2 \\
\text { weeks with } \\
\text { instruction } \\
\text { when to call } \\
\text { their } \\
\text { physician, a } \\
\text { weight gain } \\
\text { scale and a } \\
\text { daily diary to } \\
\text { complete. } \\
\text { *Patients in }\end{array}$ & $\begin{array}{l}\text { Self-care } \\
\text { management } \\
\text { and heart } \\
\text { failure } \\
\text { knowledge. }\end{array}$ & $\begin{array}{l}\text { The investigators found } \\
\text { that self-care and heart } \\
\text { failure knowledge } \\
\text { scores significantly } \\
\text { improved and } \\
\text { concluded that Teach- } \\
\text { back was an effective } \\
\text { teaching strategy to } \\
\text { improve knowledge of } \\
\text { patients concerning } \\
\text { heart failure. }\end{array}$ \\
\hline
\end{tabular}




\begin{tabular}{|c|c|c|c|c|}
\hline & & $\begin{array}{l}\text { the usual care } \\
\text { group received } \\
\text { a scale and } \\
\text { written } \\
\text { information. }\end{array}$ & & \\
\hline $\begin{array}{l}\text { Howie- } \\
\text { Esquivel, } \\
\text { White, } \\
\text { Carroll \& } \\
\text { Brinker } \\
\text { (2011) }\end{array}$ & $\begin{array}{l}\text { To determine } \\
\text { whether older } \\
\text { hospitalized } \\
\text { patients educated } \\
\text { with the Teach- } \\
\text { back } \\
\text { method can learn } \\
\text { and retain self-care } \\
\text { information } \\
\text { following hospital } \\
\text { discharge. }\end{array}$ & $\begin{array}{l}\text { Prospective } \\
\text { observational } \\
\text { study } \\
\text { Number of } \\
\text { patients } \\
\text { participating in } \\
\text { the study was } \\
265 \text { and all } \\
\text { patients were } \\
65 \text { years of age } \\
\text { or more. } \\
\text { Patients were } \\
\text { instructed on } \\
\text { four } \\
\text { categories: } \\
\text { high salt } \\
\text { foods, when to } \\
\text { call their } \\
\text { physician, } \\
\text { when to report } \\
\text { weight gain } \\
\text { and use of } \\
\text { diuretics. }\end{array}$ & $\begin{array}{l}\text { Recall of } \\
\text { four categories: } \\
\text { high salt foods, } \\
\text { when to call } \\
\text { their physician, } \\
\text { when to report } \\
\text { weight gain } \\
\text { and use of } \\
\text { diuretics. }\end{array}$ & $\begin{array}{l}\text { The data indicated that } \\
84 \% \text { of patients could } \\
\text { correctly address } 3 \text { of } \\
\text { the } 4 \text { categories } \\
\text { immediately after } \\
\text { teaching and that } 77 \% \\
\text { of patients answered } \\
75 \% \text { of the questions } \\
\text { correctly when } \\
\text { contacted post- } \\
\text { discharge. The } \\
\text { investigators concluded } \\
\text { that Teach-back was an } \\
\text { effective method to } \\
\text { teach self-care } \\
\text { behaviors for } \\
\text { hospitalized heart } \\
\text { failure patients. }\end{array}$ \\
\hline $\begin{array}{l}\text { Kandula, } \\
\text { Malli \& } \\
\text { Zei (2011) }\end{array}$ & $\begin{array}{l}\text { To answer: } \\
\text { 1) How much } \\
\text { knowledge is } \\
\text { retained } 2 \text { weeks } \\
\text { after viewing a } \\
\text { MDEP(multimedia } \\
\text { diabetes } \\
\text { educational } \\
\text { program)? } \\
\text { 2) Does } \\
\text { knowledge } \\
\text { retention differ } \\
\text { across literacy } \\
\text { levels? And }\end{array}$ & $\begin{array}{l}\begin{array}{l}\text { Prospective } \\
\text { observational } \\
\text { study }\end{array} \\
\text { Experiment } 1 \\
\text { (n=113) } \\
\\
\text { Experiment } 2 \\
\text { (n=158) } \\
\text { Experiment 1: } \\
\text { participants } \\
\text { were asked } \\
\text { knowledge }\end{array}$ & $\begin{array}{l}\text { Pre-test/Post- } \\
\text { test } \\
2 \text { MDEP } \\
\text { modules: } \\
\text { Module 1) } \\
\text { Basic } \\
\text { information } \\
\text { about diabetes } \\
\text { Including } \\
\text { definition, } \\
\text { etiologies, risk } \\
\text { factors, long } \\
\text { term outcomes } \\
\text { for diabetes } \\
\text { and basic }\end{array}$ & $\begin{array}{l}\text { The investigators found } \\
\text { that in spite of well- } \\
\text { designed programs and } \\
\text { Teach-back, few } \\
\text { patients can achieve } \\
\text { long-term retention and } \\
\text { further research is } \\
\text { needed to find more } \\
\text { effective alternatives to } \\
\text { Teach-back. }\end{array}$ \\
\hline
\end{tabular}




\begin{tabular}{|c|c|c|c|c|}
\hline & $\begin{array}{l}\text { 3) Does adding } \\
\text { Teach-back } \\
\text { protocol after } \\
\text { MDEP improve } \\
\text { knowledge } \\
\text { retention at } 2 \\
\text { weeks follow up? }\end{array}$ & $\begin{array}{l}\text { questions prior } \\
\text { to watching } \\
\text { the MDEP and } \\
\text { then they were } \\
\text { asked the same } \\
\text { questions after } \\
\text { the MDEP. } \\
\text { Knowledge } \\
\text { questions were } \\
\text { asked again } \\
\text { two weeks } \\
\text { later. } \\
\text { Experiment 2: } \\
\text { The } \\
\text { methodology } \\
\text { was exactly } \\
\text { the same, } \\
\text { although if } \\
\text { participants } \\
\text { failed to } \\
\text { answer } \\
\text { questions } \\
\text { correctly, } \\
\text { Teach-back } \\
\text { was used to } \\
\text { reinforce the } \\
\text { teaching up to } \\
\text { two times. } \\
\text { Knowledge } \\
\text { levels were } \\
\text { then assessed } \\
\text { again at the } \\
\text { two week } \\
\text { mark. }\end{array}$ & $\begin{array}{l}\text { management } \\
\text { concepts } \\
\text { Module 2) } \\
\text { Information } \\
\text { about the } \\
\text { normal, high, } \\
\text { low blood } \\
\text { glucose ranges } \\
\text { and builds on } \\
\text { concepts of } \\
\text { first module. }\end{array}$ & \\
\hline $\begin{array}{l}\text { Kripalani, } \\
\text { Bengtzen, } \\
\text { Henderson } \\
\& \\
\text { Jacobson, } \\
(2008)\end{array}$ & $\begin{array}{l}\text { To assess the } \\
\text { comprehension of } \\
\text { informed consent } \\
\text { and privacy } \\
\text { information } \\
\text { among patients } \\
\text { using the Teach- } \\
\text { back patient } \\
\text { education } \\
\text { methodology. }\end{array}$ & \begin{tabular}{|l|}
$\begin{array}{l}\text { Prospective } \\
\text { observational } \\
\text { study }\end{array}$ \\
Subjects were \\
part of a larger \\
study \\
measuring \\
cardiovascular \\
medication \\
adherence. Out \\
of 968 patients \\
\end{tabular} & $\begin{array}{l}\text { Comprehension } \\
\text { of information } \\
\text { given in } \\
\text { structured } \\
\text { Overview: } \\
\text { 1) Patients } \\
\text { could end up in } \\
\text { one of four } \\
\text { study groups } \\
\text { 2) Risks and } \\
\text { benefits of } \\
\text { participation }\end{array}$ & $\begin{array}{l}\text { The results of the study } \\
\text { indicated that patients } \\
\text { could correctly recall } \\
\text { individual items on the } \\
\text { first attempt } 57 \% \text { - } \\
92.5 \% \text { of the time but } \\
\text { only } 38.9 \% \text { of } \\
\text { participants could } \\
\text { correctly Teach-back all } \\
\text { eight of the items on } \\
\text { their first attempt. The } \\
\text { investigators concluded }\end{array}$ \\
\hline
\end{tabular}




\begin{tabular}{|c|c|c|c|c|}
\hline & & $\begin{array}{l}\text { screened, 435 } \\
\text { actually } \\
\text { participated. } \\
\text { Patients } \\
\text { received } \\
\text { information in } \\
\text { three } \\
\text { sequential } \\
\text { steps: 1) } \\
\text { patients were } \\
\text { asked to look } \\
\text { over written } \\
\text { informed } \\
\text { consent and } \\
\text { HIPAA forms } \\
\text { 2) patients } \\
\text { heard a } \\
\text { scripted study } \\
\text { overview that } \\
\text { included the } \\
\text { purpose of the } \\
\text { study and that } \\
\text { patients would } \\
\text { be interviewed } \\
\text { that day and } \\
\text { again in three } \\
\text { months } \\
\text { 3) An } \\
\text { interviewer } \\
\text { assessed } \\
\text { comprehension } \\
\text { of the patients } \\
\text { using Teach- } \\
\text { back and } \\
\text { provided } \\
\text { additional } \\
\text { training as } \\
\text { needed. }\end{array}$ & $\begin{array}{l}\text { 3) } \\
\text { Compensation } \\
\text { 4) Study access } \\
\text { to their medical } \\
\text { records } \\
\text { 5) Procedures } \\
\text { to protect } \\
\text { confidentiality } \\
\text { 6) Potential } \\
\text { need to } \\
\text { disclose } \\
\text { information to } \\
\text { regulatory } \\
\text { agencies } \\
\text { 7) Option not } \\
\text { to participate } \\
\text { 8) How to } \\
\text { withdraw from } \\
\text { study }\end{array}$ & $\begin{array}{l}\text { that the findings of the } \\
\text { data were related to the } \\
\text { literacy level of the } \\
\text { patients and did not } \\
\text { dismiss the importance } \\
\text { of Teach-back. They } \\
\text { strongly expressed their } \\
\text { support for the adoption } \\
\text { of the Teach-back } \\
\text { patient education } \\
\text { methodology as the } \\
\text { preferred method of } \\
\text { providing education to } \\
\text { patients. }\end{array}$ \\
\hline $\begin{array}{l}\text { Wilson, } \\
\text { Baker, } \\
\text { Nordstrom } \\
\& \\
\text { Legwand, } \\
\text { (2008) }\end{array}$ & $\begin{array}{l}\text { To assess the } \\
\text { ability of mothers } \\
\text { to communicate } \\
\text { benefits, risks and } \\
\text { safety of } \\
\text { pneumonia and } \\
\text { polio vaccines }\end{array}$ & $\begin{array}{l}\begin{array}{l}\text { Prospective } \\
\text { Observational } \\
\text { study }\end{array} \\
30 \text { participants }\end{array}$ & $\begin{array}{l}\text { Ability to } \\
\text { communicate } \\
\text { benefits, risks, } \\
\text { and safety of } \\
\text { pneumonia and } \\
\text { polio vaccines }\end{array}$ & $\begin{array}{l}\text { The investigators } \\
\text { concluded that the } \\
\text { results of the study were } \\
\text { mixed and attributed } \\
\text { those findings not to the } \\
\text { use of Teach-back but } \\
\text { rather more to the age }\end{array}$ \\
\hline
\end{tabular}




\begin{tabular}{|c|c|c|c|c|}
\hline & $\begin{array}{l}\text { following } \\
\text { education given } \\
\text { via Teach-back. }\end{array}$ & & & $\begin{array}{l}\text { and literacy levels of } \\
\text { the mothers who may } \\
\text { not have the verbal } \\
\text { skills needed to } \\
\text { successfully Teach- } \\
\text { back educational } \\
\text { material given to them. }\end{array}$ \\
\hline $\begin{array}{l}\text { Wilson, } \\
\text { Mayeta- } \\
\text { Peart, } \\
\text { Parada- } \\
\text { Webster \& } \\
\text { Nordstrom, } \\
\text { (2012) }\end{array}$ & $\begin{array}{l}\text { To determine if } \\
\text { Teach-back made } \\
\text { a difference in a } \\
\text { mother's } \\
\text { comprehension of } \\
\text { the importance of } \\
\text { childhood } \\
\text { vaccinations. }\end{array}$ & 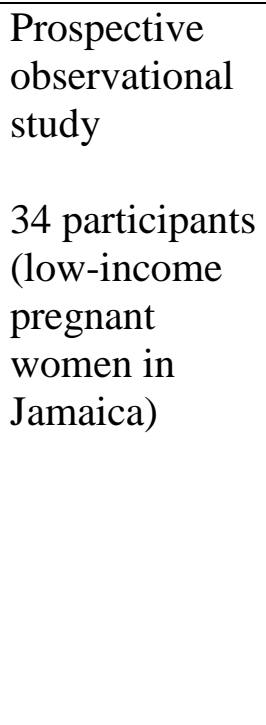 & $\begin{array}{l}\text { 1) the maternal } \\
\text { health literacy } \\
\text { of pregnant } \\
\text { women in } \\
\text { Jamaica } \\
\text { 2) ability to } \\
\text { communicate } \\
\text { the benefits, } \\
\text { risks and safety } \\
\text { of the bacillus } \\
\text { Calmette- } \\
\text { Guerin (BCG) } \\
\text { and hepatitis B } \\
\text { (hep B) }\end{array}$ & $\begin{array}{l}\text { The investigators found } \\
\text { health literacy } \\
\text { positively correlated } \\
\text { with BCG risks and } \\
\text { with hepatitis B benefits } \\
\text { and risks. Further, they } \\
\text { found no statistical gain } \\
\text { for using Teach-back in } \\
\text { women with lower } \\
\text { literacy levels, however } \\
\text { there may have been } \\
\text { benefit when using } \\
\text { Teach-back in women } \\
\text { who have higher } \\
\text { literacy levels. }\end{array}$ \\
\hline
\end{tabular}

Table 3

Comprehension and Retention of Information on Specific Outcomes

\begin{tabular}{|l|l|l|l|l|}
\hline $\begin{array}{l}\text { Author(s) and } \\
\text { Year }\end{array}$ & $\begin{array}{l}\text { Aims, Research } \\
\text { Questions or } \\
\text { Hypotheses }\end{array}$ & $\begin{array}{l}\text { Study Design } \\
\text { and Sample } \\
\text { Size }\end{array}$ & $\begin{array}{l}\text { Measured } \\
\text { Outcomes }\end{array}$ & Results \\
\hline Dantic (2014) & $\begin{array}{l}\text { To determine the } \\
\text { effectiveness of } \\
\text { Teach-back on } \\
\text { teaching COPD } \\
\text { patients how to } \\
\text { self-manage their } \\
\text { respiratory } \\
\text { inhalers }\end{array}$ & $\begin{array}{l}\text { Systematic } \\
\text { review } \\
\text { Nine studies } \\
\text { were included } \\
\text { in this review } \\
\text { of which 5 } \\
\text { were } \\
\text { randomized } \\
\text { control trials. }\end{array}$ & $\begin{array}{l}\text { Proportion of } \\
\text { correct users } \\
\text { after } \\
\text { intervention }\end{array}$ & $\begin{array}{l}\text { All studies included in } \\
\text { this SR concluded that } \\
\text { using Teach-back was } \\
\text { an effective education } \\
\text { technique in converting } \\
\text { incorrect inhaler use to } \\
\text { correct inhaler use. }\end{array}$ \\
\hline $\begin{array}{l}\text { Negarandeh, } \\
\text { Mahmoodi, } \\
\text { Noktehdan, } \\
\text { Heshmat \& }\end{array}$ & $\begin{array}{l}\text { To assess the } \\
\text { impact of Teach- } \\
\text { back and pictorial } \\
\text { image education }\end{array}$ & $\begin{array}{l}\text { Randomized } \\
\text { control trial }\end{array}$ & $\begin{array}{l}\text { The level of } \\
\text { functional } \\
\text { health } \\
\text { literacy, }\end{array}$ & $\begin{array}{l}\text { The investigators } \\
\text { concluded that both } \\
\text { Teach-back and } \\
\text { pictorial image }\end{array}$ \\
\hline
\end{tabular}




\begin{tabular}{|c|c|c|c|c|}
\hline $\begin{array}{l}\text { Shakibazadeh, } \\
\text { (2013) }\end{array}$ & $\begin{array}{l}\text { strategies on } \\
\text { knowledge } \\
\text { regarding diabetes } \\
\text { and } \\
\text { medication/dietary } \\
\text { adherence among } \\
\text { type } 2 \text { diabetics } \\
\text { with low health } \\
\text { literacy. }\end{array}$ & $\begin{array}{l}135 \\
\text { participants } \\
\text { were } \\
\text { randomly } \\
\text { selected for } \\
\text { inclusion in } \\
\text { one of three } \\
\text { groups that } \\
\text { each included } \\
45 \\
\text { participants. } \\
\text { These groups } \\
\text { included a } \\
\text { control group, } \\
\text { Teach-back } \\
\text { group, and a } \\
\text { pictorial } \\
\text { image group. }\end{array}$ & $\begin{array}{l}\text { diabetes } \\
\text { knowledge } \\
\text { and } \\
\text { adherence to } \\
\text { medication } \\
\text { and diet were } \\
\text { measured and } \\
\text { compared in } \\
\text { the three } \\
\text { groups before } \\
\text { and six weeks } \\
\text { after the } \\
\text { intervention. }\end{array}$ & $\begin{array}{l}\text { education were } \\
\text { effective educational } \\
\text { strategies among type } 2 \\
\text { diabetics with low } \\
\text { health literacy. }\end{array}$ \\
\hline $\begin{array}{l}\text { Hyrkas \& } \\
\text { Wiggins, } \\
\text { (2014) }\end{array}$ & $\begin{array}{l}\text { To compare } \\
\text { medication } \\
\text { adherence and } \\
\text { readmissions in } \\
\text { patients who } \\
\text { received usual } \\
\text { care versus } \\
\text { patient-centered } \\
\text { interventions }\end{array}$ & $\begin{array}{l}\begin{array}{l}\text { Non- } \\
\text { randomized } \\
\text { control trial }\end{array} \\
303 \text { adult } \\
\text { patients } \\
\text { The patients } \\
\text { either } \\
\text { received usual } \\
\text { care } \\
\text { [medication } \\
\text { reconciliation] } \\
\text { (n=98) or } \\
\text { patient } \\
\text { centered } \\
\text { interventions } \\
\text { [teach-back } \\
\text { and tools such } \\
\text { as pill boxes] } \\
\text { (n=205) }\end{array}$ & $\begin{array}{l}\text { Medication } \\
\text { adherence } \\
\text { and } \\
\text { readmissions } \\
\text { among } \\
\text { groups }\end{array}$ & $\begin{array}{l}\text { The investigators } \\
\text { concluded that there } \\
\text { was no difference in } \\
\text { medication adherence } \\
\text { and readmissions } \\
\text { between groups. }\end{array}$ \\
\hline $\begin{array}{l}\text { Bates, } \\
\text { O’Conner, } \\
\text { Dunn \& } \\
\text { Hasenau, } \\
(2014)\end{array}$ & $\begin{array}{l}\text { To explore the } \\
\text { impact of } \\
\text { implementing } \\
\text { STAAR } \\
\text { interventions } \\
\text { (State Action on } \\
\text { Avoidable }\end{array}$ & $\begin{array}{l}\text { Observational } \\
\text { cohort study } \\
\text { A pre- } \\
\text { intervention } \\
\text { group (97) } \\
\text { and a post- }\end{array}$ & $\begin{array}{l}30 \text { day } \\
\text { readmission } \\
\text { rates and } \\
\text { patient } \\
\text { experience }\end{array}$ & $\begin{array}{l}\text { The overall 30-day } \\
\text { readmission rate for } \\
\text { CABG patients in the } \\
\text { post-intervention group } \\
\text { was decreased. } \\
\text { Patients rated Teach- } \\
\text { back as effective or }\end{array}$ \\
\hline
\end{tabular}




\begin{tabular}{|c|c|c|c|c|}
\hline & $\begin{array}{l}\text { Rehospitalizations, } \\
\text { specifically Teach- } \\
\text { back and } \\
\text { scheduling follow- } \\
\text { up cardiology } \\
\text { appointments) on } \\
\text { readmission rates } \\
\text { and experience of } \\
\text { care in CABG } \\
\text { patients }\end{array}$ & $\begin{array}{l}\text { intervention } \\
\text { group (92) }\end{array}$ & & $\begin{array}{l}\text { highly effective and } \\
\text { follow up appointments } \\
\text { were perceived as } \\
\text { convenient or very } \\
\text { convenient. }\end{array}$ \\
\hline $\begin{array}{l}\text { White, } \\
\text { Garbez, } \\
\text { Carroll, } \\
\text { Brinker \& } \\
\text { Howie- } \\
\text { Esquivel, } \\
2013\end{array}$ & $\begin{array}{l}\text { To determine if } \\
\text { hospitalized heart } \\
\text { failure patients } \\
\text { educated with the } \\
\text { Teach-back } \\
\text { method retain self- } \\
\text { care educational } \\
\text { information and } \\
\text { have fewer } \\
\text { readmissions }\end{array}$ & $\begin{array}{l}\text { Observational } \\
\text { cohort study } \\
276 \text { patients } \\
\text { older than } 65 \\
\text { years of age } \\
\text { Patients were } \\
\text { evaluated } \\
\text { prior to } \\
\text { discharge and } \\
7 \text { days later }\end{array}$ & $\begin{array}{l}\text { Teach-back } \\
\text { questions } \\
\text { 1) What is the } \\
\text { name of your } \\
\text { water pill? } \\
\text { 2) How much } \\
\text { weight gain } \\
\text { would you } \\
\text { want to report } \\
\text { to your } \\
\text { healthcare } \\
\text { provider? } \\
\text { 3) What high- } \\
\text { salt foods do } \\
\text { you need to } \\
\text { avoid/be } \\
\text { aware of? } \\
\text { 4) Please } \\
\text { name } 3 \text { to } 4 \\
\text { warning signs } \\
\text { of when you } \\
\text { want to call } \\
\text { your } \\
\text { healthcare } \\
\text { provider. } \\
30 \text { day } \\
\text { readmission } \\
\text { rates. }\end{array}$ & $\begin{array}{l}\text { The results of the study } \\
\text { indicate that } 75 \% \text { of } \\
\text { self-care Teach-back } \\
\text { questions are answered } \\
\text { correctly } 84.4 \% \text { of the } \\
\text { time while still in the } \\
\text { hospital and } 77.1 \% \text { of } \\
\text { the time during the } \\
\text { follow-up phone calls. } \\
\text { Patients who correctly } \\
\text { answered Teach-back } \\
\text { questions while } \\
\text { hospitalized and } 7 \text { days } \\
\text { later had non- } \\
\text { significant reductions } \\
\text { in } 30 \text { day readmissions } \\
\text { for all causes but a } \\
\text { trend toward } \\
\text { significance for } \\
\text { patients who were } \\
\text { readmitted with heart } \\
\text { failure. }\end{array}$ \\
\hline $\begin{array}{l}\text { Quigley et al. } \\
\text { (2009) }\end{array}$ & $\begin{array}{l}\text { To develop and } \\
\text { test a set of } \\
\text { interventions (of } \\
\text { which Teach-back } \\
\text { is included) to } \\
\text { prevent serious } \\
\text { injury from patient } \\
\text { falls. }\end{array}$ & $\begin{array}{l}\text { Prospective } \\
\text { observational } \\
\text { study } \\
2 \text { nursing } \\
\text { units were } \\
\text { included in } \\
\text { study. }\end{array}$ & $\begin{array}{l}\text { Fall rate and } \\
\text { injuries from } \\
\text { falls }\end{array}$ & $\begin{array}{l}\text { The overall results of } \\
\text { the study showed a } \\
\text { slight downward trend } \\
\text { in total fall rates per } \\
1000 \text { patient days and } \\
\text { there were no } \\
\text { significant trends for } \\
\text { minor, moderate or }\end{array}$ \\
\hline
\end{tabular}




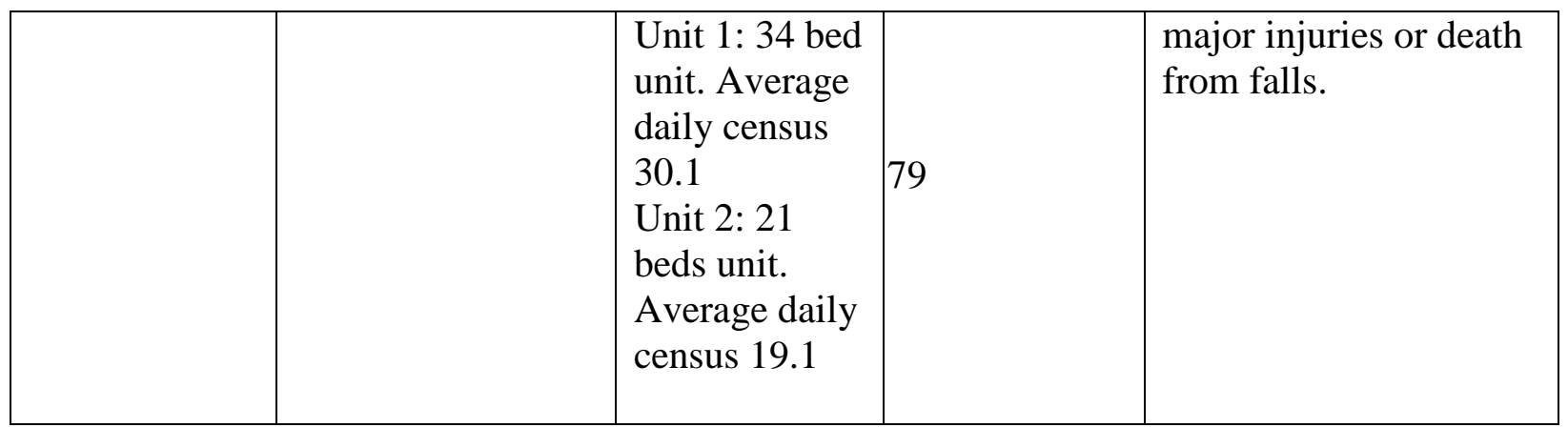




\section{Appendix G}

\section{PRISMA 2009 Flow Diagram}

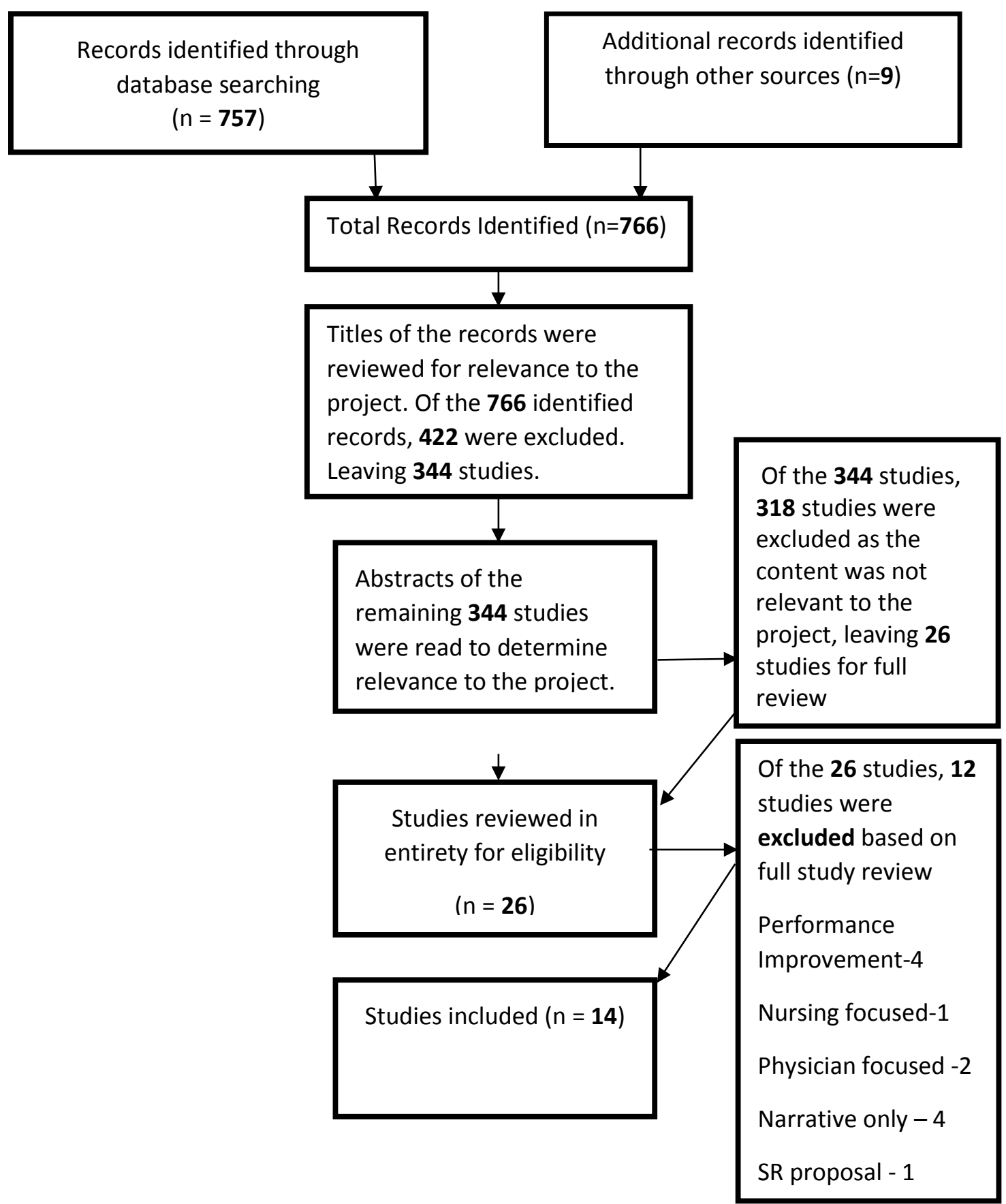

From: Moher D, Liberati A, Tetzlaff J, Altman DG, The PRISMA Group (2009). Preferred Reporting /tems for Systematic Reviews and Meta-Analyses: The PRISMA Statement. PLoS Med 6(6): e1000097. doi:10.1371/journal.pmed1000097 
Office of Research Integrity

886 Chestnut Ridge Road

P.O. Box 6845

Morgantown, WV 26506-6845

To Whom It May Concern:

I am writing on behalf of Elizabeth Bosley, an employee of St. Mary's Medical Center, and a student in the Doctor of Nursing Practice program at West Virginia University's College of Nursing.

Elizabeth will be working with the risk management and nursing departments of St. Mary's Medical Center for submission of her expedited IRB application to West Virginia University, for her clinical project entitled "Implementation of the Teach-back Patient Education Methodology for Reduction of Geriatric Falls in the Inpatient Setting". All research conducted at St. Mary's Medical Center is reviewed by the Marshall University's IRB to assure appropriateness of the project for our patient population.

Elizabeth has the full support of St. Mary's Medical Center in conducting this project and I look forward to reviewing the results once the project has concluded.

Sincerely,

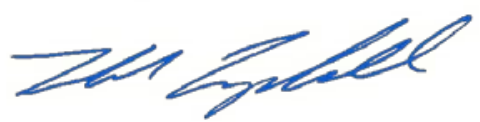

Todd Campbell

Senior Vice President/COO 


\section{Appendix I}

\section{MARSHALL UNIVERSITY.

\author{
w w w . mar $s$ ha 1 l, e d u
}

Office of Research Integrity

November 23, 2015

Jennifer Mallow, $\mathrm{Ph} . \mathrm{D}$., RN

Assistant Professor

West Virginia University

School of Nursing

9620 HSC South, Morgantown, WV 26506

Dear Dr. Mallow:

This letter is in response to the study that was approved by the West Virginia University (WVU) Institutional Review Board (IRB) titled "Implementation and evaluation of Teachback as a pedagogical method for delivering fall prevention education to older adults in an impatient hospital setting." We have conducted a facilitated review and are in agreement with the WVU IRB. You have permission to conduct the study at St. Mary's Medical Center in accordance with the WVU IRB approved protocol. The Code of Federal Regulations (45CFR46) has set forth the criteria utilized in making this determination. If there are any modifications to the study requiring IRB approval please submit a description of the modification along with a copy of the WVU IRB modification approval letter to the Marshall University Office of Research Integrity for administrative review.

I appreciate your willingness to submit the study for an administrative review. Please feel free to contact the Office of Research Integrity with any questions or if modifications to the study are required.

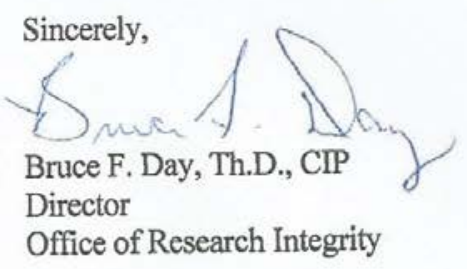




\section{W-West VurginiaUniversity. \\ Office of Research Integrity and Compliance \\ Ba6 CMESNUT RLDER ROAD MORGANTOWN, WV 25806}

\section{Approval Letter Expedited}

\section{Action Date \\ To \\ From \\ Approval Date \\ Expiration Date \\ Subject \\ Protocol Number}

Title
$11 / 18 / 2015$

Jennifer Mallow

WVU Office of Research Integrity and Compliance

$11 / 18 / 2015$

$11 / 17 / 2016$

Protocol Approval Letter

1510873600

"Implementation and Evaluation of Teach-back as a Pedagogical Method for Delivering Fall Prevention Education to Older Adults in an Inpatient Hospital Setting:. In the United States, the most common cause of both nonfatal injuries and accidental deaths for people older than 65 is falls. In the hospital setting, 700,000 to $1,000,000$ falls occur annually resulting in increased cost and reduced reimbursement. Older adult patients who fall in the hospital may experience pain and incur disabilities so severe they may require short or long term care post-hospitalization and may lose their independence permanently. There exists a critical need to explore potential interventions for effectiveness in reducing both the incidence and severity of falls. The purpose of this project is to implement and evaluate Teach-back as a pedagogical method for delivering fall prevention education to older adults in an inpatient hospital setting. Teach-back is an evidence-based patient education methodology which requires the patient to repeat in their own words the education they have been given by the nurse. The nurse can then evaluate if further teaching is warranted. Teach-back provides a way for patients to become active participants in their own care by providing them with the knowledge they need to execute self-care behaviors resulting in a decreased chance for falls. In this project, nurses on one nursing unit will be trained in the Teach-back methodology and will deliver scripted falls prevention education to each patient admitted to the unit. Nurses will be observed for the use and documentation of Teach-back to decrease falls in patients 65 years of age and older. The rate of falls and falls with injury will also be evaluated.

The above-referenced research study was reviewed by the West Virginia University Institutional Review Board IRB and was approved in accordance with 46 CFR $46.101 \mathrm{~b}$.

It has been determined that this study is of minimal risk and meets the criteria as defined by the expedited categories listed below: 
- Category 7. Research on individual or group characteristics or behavior (including, but not limited to, research on perception, cognition, motivation, identity, language, communication, cultural beliefs or practices, and social behavior) or research employing survey, interview, oral history, focus group, program evaluation, human factors evaluation, or quality assurance methodologies. [NOTE: Some research in this category may be exempt from the DHHS regulations for the protection of human subjects. See Exempt Categories and 45 CFR 46.101(b)(2) and (b)(3). This listing refers only to research that is not exempt.]

- Category 4. Collection of data through noninvasive procedures (not involving general anesthesia or sedation) routinely employed in clinical practice, excluding procedures involving $\mathrm{x}$-rays or microwaves. Where medical devices are employed, they must be cleared/approved for marketing. (Studies intended to evaluate the safety and effectiveness of the medical device are not generally eligible for expedited review, including studies of cleared medical devices for new indications.) Examples: (a) physical sensors that are applied either to the surface of the body or at a distance and do not involve input of significant amounts of energy into the subject or an invasion of the subjects privacy; (b) weighing or testing sensory acuity; (c) magnetic resonance imaging; (d) electrocardiography, electroencephalography, thermography, detection of naturally occurring radioactivity, electroretinography, ultrasound, diagnostic infrared imaging, doppler blood flow, and echocardiography; (e) moderate exercise, muscular strength testing, body composition assessment, and flexibility testing where appropriate given the age, weight, and health of the individual.

Documents reviewed and/or approved as part of this submission:

Todd Campbell letter.pdf: 2015-10-09-04:00

Scientific Rationale.docx: 2015-10-22-04:00

Teach-back observation tool (pre-intervention).docx: 2015-11-08-05:00

Teach-back observation tool (post-intervention).docx: 2015-11-08-05:00

Data Collection Tools.docx: 2015-11-08-05:00

COVER LETTER.docx: 2015-11-08-05:00

Protocol Summary.docx: 2015-11-09-05:00

Protocol Chronology Revised.docx: 2015-11-09-05:00

Teach Back Training for Registered Nurses.docx: 2015-11-08-05:00

Fall Prevention Teach.docx: 2015-11-08-05:00

Nursing Teach-back Guide for Patient Education.docx: 2015-11-08-05:00

HIPAA_Waiver_Form REVISED.docx: 2015-11-08-05:00 
HIPAA_Waiver_Form REVISED (2).docx: 2015-11-08-05:00

Consent OMR 2013.04.03 PATIENT.pdf: 2015-11-09-05:00

Consent OMR wo HIPAA 2013.04.03 NURSE.pdf: 2015-11-09-05:00

Vice President Patient Services 626 08.doc: 2015-11-09-05:00

Documents for use in this study are available in the WVUkc system in the Notes and Attachments section of your protocol.

The Office of Research Integrity and Compliance is here to provide assistance to you from the initial submission of an IRB protocol and all subsequent activity. Please feel free to contact us by phone at 304.293.7073 with any question you may have. Thank you.

WVU Office of Research Integrity and Compliance

Date:11/18/2015

Signed:

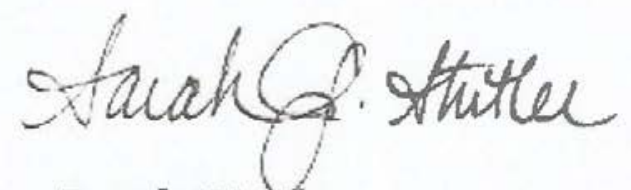

\section{Sarah Stutler}

\section{IRB Administrator}

ving regulations apply:

1. Unanticipated or serious adverse events/side effects encountered in this research study must be reported to the IRB within five (5) days via the Notify IRB action.

2. Any modifications to the study protocol or informed consent form must be reviewed and approved by the IRB prior to implementation via submission of an amendment.

3. You may not use a modified informed consent form until it has been approved and validated by the IRB. 


\section{Appendix $\mathbf{J}$}

Agency for Healthcare Quality and Research Formulas for Falls per 1000 patient days and Falls with Injury per 1000 patient days

- Total Falls: (Number of Patient Falls X 1000)/Total Number of Patient Days - Injury Falls: (Number of Patient Injury Falls X 1000)/Total Number of Patient Days

Source: Agency for Healthcare Research and Quality Preventing Falls in Hospitals (2013) Preventing falls in hospitals: How do you measure fall rates and fall prevention practices? Retrieved from: http://www.ahrq.gov/professionals/systems/hospital/fallpxtoolkit/fallpxt 5.html 


\section{Curiculum Vitae}

\section{Elizabeth Ann Hutchinson

\section{Education}

Professional experience

\section{Doctor of Nursing Practice (DNP)}

Graduation Date: August 12,2016 (tentative)

West Virginia University

Morgantown, WV

\section{Master of Science in Nursing (MSN)}

Graduation: December 28,1990

West Virginia University

Morgantown, WV

\section{Bachelor of Science in Nursing (BSN)}

Graduation: May 17,1987

West Virginia University

Morgantown, WV

\section{Diploma in Nursing}

Graduation: May 10,1980

St. Mary's School of Nursing

Huntington, WV 25701

Vice President of Patient Senvices/Chief Nursing Officer

St. Mary's Medical Center

2900 First Avenue

Huntington, WV 25702

August 2007 - Present 


\section{Director of Nursing}

St. Mary's Medical Center

2900 First Avenue

Huntington, WV 25702

2003-2007

\section{Assoc iate Director of Nursing}

St. Mary's Medical Center

Huntington, WV 25702

1998-2003

\section{Director of Critical Care Services}

St. Mary's Medical Center

Huntington, WV 25702

1992-1998

\section{Adjunct Clinical Faculty}

Marshall University

Huntington, WV 25701

(One semester only, acted as a clinical instructor)

\section{Level I Nursing Instructor}

St. Mary's School of Nursing

Huntington, WV 25701

1989-1992

\section{Critical Care Educator}

St. Mary's Medical Center

Huntington, WV 25702

1985-1989

Staff Nurse Surgical Service Intensive Care Unit

St. Mary's Medical Center

Huntington, WV 25702

1980-1985 


\section{Additional professional activities} Professional
memberships
Sigma Theta Tau International Honor Society of Nursing

Fellow of the American College of Healthcare Executives (FACHE) September 2015-present

ANCC: Nurse Executive Advanced: (NEA-BC) 2004 - Present

AACN: Critical Care Registered Nurse (CCRN) 1996-1990

West Virginia Nursing Leadership Institute: November 2005-October 2007

American College of Healthcare Executives

American Organization of Nurse Executives

West Virginia Organization of Nurse Executives

American Nurses Association

West Virginia Nurses Association

West Virginia: License Number 304120

Ohio: License Number 411409 
